\title{
23. CALCAREOUS NANNOFOSSILS FROM CORES RECOVERED ON LEG 4
}

\author{
W. W. Hay, Rosenstiel School of Marine and Atmospheric Sciences, \\ University of Miami, Miami, Florida, and Department of Geology, \\ University of Illinois, Urbana, Illinois
}

\section{INTRODUCTION}

This study of the calcareous nannoplankton fossils found in samples from cores recovered on Leg 4 of the Deep Sea Drilling Project represents a preliminary survey. Information on the abundance and preservation of calcareous nannofossils in the core sections is presented in another section of this volume which deals with the detailed description of the cores. This section is devoted to an account of the species present in the samples, their relative abundances, and discussion of the nannoplankton biostratigraphy of the cores. This survey is not a thorough account of the occurrences in the Leg 4 materials; but, rather, it is intended to serve as a source of information to guide interested workers to areas which would yield fruitful results from detailed investigation.

Leg 4 cores have provided almost no assemblages of calcareous nannofossils older than the Middle Eocene. Middle and Late Eocene assemblages are sparse and, generally, corroded in these cores. No Early Oligocene assemblages were found. Late Oligocene, Miocene, Pliocene and Pleistocene assemblages were each encountered at two or more sites. Only three of the sites drilled on Leg 4 were in depths such that the entire sedimentary sequence sampled was deposited above the calcium carbonate compensation level; these were Site 25 at 1916 meters (6286 feet), Site 30 at 1218 meters (3994 feet) and Site 31 at 3369 meters $(11,049$ feet). At all of the other sites drilled on this leg, at least part of the sampled section was devoid of calcareous nannofossils due to solution. There is some evidence that solution within the carbonate compensation zone is selective, removing some genera before other forms show any sign of corrosion. This effect is most strikingly displayed in the radiolarian ooze of Eocene age at Site 29. In this sediment, calcareous nannofossils are present at only a few levels. In some samples, only a single species, Discoaster barbadiensis, is present, but at a few levels more diverse assemblages occur. Selective solution may account for the absence of some stratigraphically useful species in other sections.

As noted above, most of the calcareous nannofossils recovered on Leg 4 are of Late Oligocene-Pleistocene age. Unfortunately, only about one-half of the readily differentiated morphological types common in this interval have been formally named. Accordingly, the species concepts for calcareous nannofossils in this interval tend to be broad, sometimes obscuring the stratigraphic value of certain forms. The species which have been identified in the samples that were studied are listed below, together with comments on recognition, variability and differentiation from similar forms where required. Species abundances are recorded as the logarithm of abundance in a simple smear slide viewed at $1000 \mathrm{X}$. The number " 2 " indicates hundreds of specimens in a single field of view; " 1 " is the equivalent of tens of specimens in a single field of view; " 0 " indicates a single specimen in each field of view; "-1" indicates a single specimen in every ten fields of view; "- 2 " is a single specimen in every hundred fields of view; and, " -3 " denotes a single specimen in a thousand fields of view. The relative abundance is expressed in terms of order of magnitude, a measure that is expected to be meaningful and reproducible.

\section{SYSTEMATIC PALEONTOLOGY}

The following inventory of species is necessarily incomplete, since not all of the forms encountered could be assigned to previously described taxa. References to the original descriptions and figures can be obtained by consulting the "Annotated index and bibliography of the calcareous nannoplankton" by Loeblich and Tappan $(1966,1968,1969)$. For those species which have been described since the most recent supplement of the Loeblich and Tappan Index, and for those taxa formally transferred to another genus here, reference to the original description and figure is given below.

Papers which proved to be of especial use in identification of the calcareous nannofossils included: Gartner (1968 and 1969), Bramlette and Sullivan (1961), Hay, Mohler and Wade (1966), Martini and Bramlette (1963), Hay et al. (1967), Bramlette and Wilcoxon (1967), Boudreaux and Hay (1969), and Kamptner (1967).

In the following classification and on the distribution charts, genera and species are grouped by similarity of shape within the framework of a current suprageneric classification.

Class COCCO LITHOPHYCEAE Rothmaler, 1951

Family COCCOLITHACEAE Kamptner, 1928 
Subfamily COCCOLITHOIDEAE Kamptner, 1928

Tribe GEPHYROCAPSEAE Boudreaux and Hay, 1969

Genus Emiliania Hay and Mohler, 1967

Emiliania huxleyi (Lohmann) (ex Pontosphaera): This species is characterized by "I"-shaped shield elements and a central grille. Only larger specimens can be identified with certainty in the light microscope. According to McIntyre (in press), this species appeared between 140,000 and 200,000 years ago. It was found only in piston cores taken by the Vema for site survey at Site 25 .

\section{Genus Gephyrocapsa Kamptner, 1943}

Gephyrocapsa oceanica Kamptner:

Distinguished by having a bridge inclined $20^{\circ}$ or less to the minor axis of the ellipse, this species is robust, and readily recognized in the light microscope. It is restricted to Late Pleistocene and younger sediments.

Gephyrocapsa aperta Kamptner:

Differs from G. oceanica in having a more coarsely constructed bridge, more broadly open central area, and in the inclination of the bridge which makes an angle of 70 to $80^{\circ}$ with the minor axis of the ellipse. Its first occurrence is slightly below that of $G$. oceanica.

Gephyrocapsa caribbeanica Boudreaux and Hay:

This species is differentiated from the two above by having a wider bridge which closes most or all of the central area. It tends to be very small in the earlier part of its range, increasing in size to its point of extinction shortly after the appearance of $G$. ocean$i c a$. The base of the range of G. caribbeanica is probably in the Discoaster brouweri Zone.

\section{Genus Pseudoemiliania Gartner, 1969}

Pseudoemiliania lacunosa Kamptner ex Gartner (1969): Kamptner (1963, Plate 9, Figure 50) described and figured the species $E$. lacunosus, type of the provisionally proposed genus Ellipsoplacolithus. Because provisional names are not valid under the International Code of Botanical Nomenclature (Article 34), the genus and species proposed under it were invalid. Gartner (1969), apparently unaware that the species had never been validated or that $E$. lacunosus had been intended as the type species of Ellipsoplacolithus, proposed the new genus Pseudoemiliania, designating $E$. lacunosus as its type species. From Gartner's discussion, it is evident that he did not consider the new genus Pseudoemiliania to be in any way provisional, and his citation and discussion of the species $P$. lacunosus attributed to Kamptner may be construed to have validated the species. The genus Ellipsoplacolithus was never validated, so that Gartner's validation of the species and its assignment to Pseudoemiliania are correct. This species is characterized by construction similar to that of E. huxleyi, but on a much more robust scale. The "I"-shaped rim elements are clearly discernable in the light microscope when observed between crossed polarizers. The lowest occurrence of this species is in the Reticulofenestra pseudoumbilica Zone according to Gartner (1969), and its highest occurrence is in the Gephyrocapsa oceanica Zone. Two forms of the species have been recognized in the course of the present investigation, one with a circular outline in plan view, the other oval in plan view. These two forms have different ranges and acmes. The acme of the circular form is in the later part of the range of the species.

\section{Tribe COCCOLITHEAE Kamptner, 1958}

Genus Watznaueria Reinhardt, 1964

Watznaueria barnesae (Black) (ex Tremalithus):

Encountered only in samples from the lower part of the hole at Site 28. Members of this Cretaceous genus differ from the homeomorphous Tertiary Coccolithus in displaying an interference cross in the distal shield when viewed between crossed polarizers.

\section{Genus Coccolithus Schwarz, 1894}

Coccolithus pelagicus (Wallich) (ex Cyathosphaera): Used here to include a number of closely related Tertiary forms.

Coccolithus eopelagicus (Bramlette and Riedel) (ex Tremalithus):

This species is distinguished from C. pelagicus by its larger size and heavy construction. Usually restricted to Upper Eocene-Lower Miocene strata, this species was found in Middle Miocene samples from Site 30 .

Coccolithus pseudocarteri Hay, Mohler and Wade: This species is the Upper Eocene-Lower Miocene homolog of C. carteri.

\section{Genus Reticulofenestra Hay, Mohler and Wade, 1966}

Reticulofenestra bisecta (Hay, Mohler and Wade) (ex Syracosphaera):

Stradner and Edwards (1968) have considered this species to be synonymous with Reticulofenestra placomorpha (Kamptner), but in the present study it seems useful to separate the two forms as they have different stratigraphic ranges.

Reticulofenestra umbilica (Levin) (ex Coccolithus): This species was also considered by Stradner and Edwards to be synonymous with $R$. placomorpha (Kamptner), but it may be possible to separate these forms from one another. $R$. placomorpha was originally described from the Miocene; $R$. umbilica from the Upper Eocene. 
Reticulofenestra pseudoumbilica (Gartner) (ex Coccolithus):

This Late Miocene-Pliocene species closely resembles the Late Eocene-Early Oligocene $R$. umbilica. However, no intermediate form occurs in the Middle Oligocene-Middle Miocene. R. pseudoumbilica appears to be relatively sensitive to solution, and is absent from Late Miocene-Pliocene assemblages from deeper holes.

Reticulofenestra laevis Roth and Hay:

This subcircular species appears to be a smooth disc in the light microscope. It was found in the Helicopontosphaera ampliaperta Zone at Site 29 (Hole 29B).

Genus Chiasmolithus Hay, Mohler and Wade, 1966

Chiasmolithus gigas (Bramlette and Sullivan) (ex Coccolithus):

This Middle Eocene species was found at Site 28.

Chiasmolithus grandis (Bramlette and Riedel) (ex Coccolithus):

Characteristic of the Middle and Late Eocene, this species is, from its occurrence in the radiolarian ooze at Site 29, relatively resistant to solution. The cross is attacked first. The isolated rims of Chiasmolithus recorded on Table 13 (Site 29) probably belong to C. grandis.

\section{Subfamily CYCLOCOCCOLITHOIDEA E Hay and Mohler, 1969}

Tribe CYCLOCOCCOLITHEAE Boudreaux and Hay, 1969

Genus Cyclococcolithus Kamptner, 1954

Cyclococcolithus floridanus (Roth and Hay) n. comb. (= Coccolithus floridanus Roth and Hay in Hay et al., 1967, p. 445, Plate 6, Figures 1 through 4):

A very similar form, Cyclococcolithus neogammation Bramlette and Wilcoxon, is considered to be con-specific. C. floridanus is extremely abundant in Oligocene and Lower Miocene samples.

Cyclococcolithus leptoporus (Murray and Blackman) (ex Coccosphaera):

The variation in abundance of this species in Pleistocene sections is interesting and may have paleoclimatological significance.

Tribe UMBILICOSPHAEREAE Boudreaux and Hay, 1969

\section{Genus Umbilicosphaera Lohmann, 1902}

Umbilicosphaera mirabilis Lohmann:

Considerable variation is noted in this species in the Pleistocene, both in abundance and in form. Its first occurrence seems to be in the Early Pliocene.
Umbilicosphaera cricota (Gartner) (ex Cyclococcolithus):

Characteristic of this species are the irregular gaps between some elements of the rim. Stratigraphically, this species preceeds $U$. mirabilis, but its structure is sufficiently different that it cannot be regarded as the ancestor of the latter.

Umbilicosphaera humilis (Kamptner) n. comb. (=Cyclolithus humilis Kamptner, 1956, p. 9):

This species is best placed in Umbilicosphaera. It was found only in the Late Miocene-Early Pliocene at Site 25 .

Genus Coronocyclus Hay, Mohler and Wade, 1966

Coronocyclus nitescens (Kamptner) (ex Umbilicosphaera):

This species is characteristic of Early Miocene assemblages. It is distinguished by its relatively strong relief.

Genus Cyclolithella Loeblich and Tappan, 1963

Cyclolithella annula (Cohen) (ex Coccolithites):

This species, with its very wide central opening, appears to be restricted to the upper part of the Gephyrocapsa oceanica Zone and younger strata.

Family EIFFELLITHACEAE Reinhardt, 1965

Genus Eiffellithus Reinhardt, 1964

Eiffellithus turriseiffeli (Deflandre) (ex Zygolithus): This characteristic Upper Cretaceous species was found only in samples from the deeper part of the hole at Site 28.

Family ARKHANGELSKIELLACEAE Bukry, 1969

Genus Arkhangelskiella Vekshina, 1959

Arkhangelskiella scapha Gartner:

The presence of this species in the sample of the Upper Cretaceous from Site 28 suggests a Santonian or Campanian age for some of the sediment.

Family PODORHABDACEAE Noel, 1965

Genus Prediscosphaera Vekshina, 1959

Prediscosphaera cretacea (Arkhangelskii) (ex Coccolithophora):

The presence of this ubiquitous Upper Cretaceous species in a sample from the lower part of the hole at Site 28 is noted.

Family PONTOSPHAERACEAE Lemmermann, 1908

Genus Pontosphaera Lohmann, 1902 
Pontosphaera scutellum Kamptner:

This has been used here as a general category for all pontosphaerids which lack a high wall and which do not display pores when observed in the light microscope. Closer examination of the samples would undoubtedly reveal the presence of a number of different morphotypes.

Pontosphaera discopora Schiller:

This has been used on the distribution charts as a general term for all pontosphaerids of the Pliocene and Pleistocene which display perforate bases when observed in the light microscope. It is evident that a number of morphotypes are involved, but the taxonomy of the group is currently in a state of confusion. Forms of this sort might better be referred to the genus Discolithina.

Genus Discolithina Loeblich and Tappan, 1963

Discolithina vigintiforata (Kamptner ex Deflandre) (ex Discolithus):

The species concept employed here is that of Bramlette and Wilcoxon (1967, Plate 5, Figures 3 and 4). The species is most common in the Late Oligocene and Early Miocene.

Discolithina anisotrema (Kamptner) (ex Discolithus): The usage of Bramlette and Wilcoxon (1967, Plate 5, Figures 5 and 6 ) is followed here as the drawings of Kamptner appear to be somewhat schematic.

"Discolithina" phaseola:

See under Aspidorhabdus.

Genus Helicopontosphaera Hay and Mohler, 1967

Helicopontosphaera kamptneri Hay and Mohler: The base of this species is imperforate, although narrow pseudoperforations appear when specimens are examined between parallel or crossed nicols.

Helicopontosphaera wallichi (Lohmann):

This species is similar to H. kamptneri, but differs in having the base pierced by two narrow slits arranged en echelon at a small angle to the long axis of the coccolith. It has been recently illustrated by Boudreaux and Hay (1969, Plate 6, Figure 9).

Helicopontosphaera cf. seminulum (Bramlette and Sullivan) (ex Helicosphaera) [Helicopontosphaera seminulum (Bramlette and Sullivan) n. comb. = Helicosphaera seminulum Bramlette and Sullivan, 1961, p. 144]: Forms similar to the Eocene species $H$. seminulum occur in the Pliocene and Pleistocene. Characteristic for these specimens are two large openings in the basal disc and a prominent bridge.

Helicopontosphaera intermedia (Martini) (ex Helicosphaera):

This species is distinguished by having a sigmoidal bar separating two openings in the base. Some stratigraphic significance may be attached to the degree of flare of the helical rim.

Helicopontosphaera parallela (Bramlette and Wilcoxon) n. comb. ( = Helicosphaera parallela Bramlette and Wilcoxon, 1967, p. 106, Plate 5, Figures 9 and 10): This species differs from $H$. intermedia in having the bar more closely aligned to the long axis of the ellipse. No openings are visible in the light microscope. This species probably has its earliest occurrence in the Late Eocene, and is common in the Oligocene and Early Miocene.

Helicopontosphaera ampliaperta (Bramlette and Wilcoxon) n.comb. (=Helicosphaera ampliaperta Bramlette and Wilcoxon, 1967, p. 105, Plate 6, Figures 1 through 4): This species is distinguished by having a large open center.

Helicopontosphaera compacta (Bramlette and Wilcoxon) n. comb. ( = Helicosphaera compacta Bramlette and Wilcoxon, 1967, p. 105, Plate 6, Figures 5 through 8):

This species has a distinctive, more rounded, outline.

Genus Transversipontis Hay, Mohler, and Wade, 1966

Transversipontis pulcher (Deflandre) (ex Discolithus): This species is distinguished from biperforate species of Helicopontosphaera by having a continuous, not spiral, rim.

Genus Crassapontosphaera Boudreaux and Hay, 1969

Crassapontosphaera jonesi Boudreaux and Hay (1969, Plate 5, Figures 14 through 19):

This Pleistocene species is characterized by a coarsely constructed rim. Between crossed polarizers, the rim may have an interference color as high as first order yellow.

\section{Subfamily SCYPHOSPHAEROIDEAE Boudreaux and Hay, 1969}

Genus Scyphosphaera Lohmann, 1902

Scyphosphaera spp.:

No attempt was made to speciate this genus in the present study. A number of different forms are present in the samples, but many of them do not fit readily into previously described taxa.

Family PRIN SIACEAE Hay and Mohler, 1967

\section{Genus Ericsonia Black, 1964}

Ericsonia subdisticha (Roth and Hay) (ex Ellipsolithus): This species can be recognized in the light microscope by the perforations arranged symmetrically about the long axis of the central area. In other respects, it closely resembles Coccolithus pelagicus. The base of its range is in the Middle Eocene, and the top is in the Lower Miocene. 


\section{Genus Campylosphaera Kamptner, 1963}

Campylosphaera dela (Bramlette and Sullivan) (ex Coccolithites):

The rarity of this species in oceanic sediments suggests that its preferred habitat may be coastal waters.

Family ZYGODISCACEAE Hay and Mohler, 1967

Genus Zygodiscus Bramlette and Sullivan, 1961

Zygodiscus lacunatus Gartner:

This species was found only in a sample with a Cretaceous assemblage, from the lower part of the hole at Site 28.

\section{Genus Neococcolithes Sujkowski, 1931}

Neococcolithes lososnensis Sujkowski:

This distinctive species, often recorded as Zygolithus dubius Deflandre in the literature, is rare in the Eocene sediments recovered on Leg 4. Its relative rarity in oceanic deposits suggests that it may prefer more coastal waters.

Genus Chiphragmalithus Bramlette and Sullivan, 1961

Chiphragmalithus quadratus Bramlette and Sullivan: The rarity of this species in the Middle Eocene deposits at Site 28 suggests that it may be more abundant in coastal sediments.

Family BRAAR UDOSPHAER ACEAE Deflandre, 1947

Genus Braarudosphaera Deflandre, 1947

Braarudosphaera undata Stradner:

This species in rare in the Upper Eocene at Site 28.

Braarudosphaera discula Bramlette and Riedel:

This species is rare in the Upper Eocene at Site 27.

Genus Micrantholithus Deflandre, 1954

Micrantholithus basquensis Martini:

This species is rare in the Upper Eocene at Site 28.

Family CALYPTROSPHAER ACEAE Boudreaux and Hay, 1969

Genus Zygrhablithus Deflandre, 1959

Zygrhablithus bijugatus (Deflandre) (ex Zygolithus): This species is rare in the Late Eocene at Site 28.

Family RHABDOSPHAERACEAE Lemmermann, 1908

Subfamily RHABDOSPHAEROIDEAE Kamptner, 1928
Genus Rhabdosphaera Haeckel, 1894

Rhabdosphaera clavigera Murray and Blackman: Specimens assignable to this species were encountered only at Site 31 . Most of the rhabdolithus found in samples taken on this leg show little or none of the distal expansion of the stem characteristic of $R$. clavigera.

Genus Aspidorhabdus Hay and Towe, 1962

Aspidorhabdus stylifer (Lohmann) (ex Rhabdosphaera): This species is usually present in Pleistocene and Late Pliocene samples, but varies greatly in abundance from level to level, suggesting that some climatic significance may be attached to its occurrence or nonoccurrence.

"Discolithina" phaseola (Black and Barnes) (ex Discolithus):

McIntyre and $\mathrm{Be}^{\prime}$ (1967) have noted that this coccolith occurs along with rhabdoliths on the surface of the coccosphere of Aspidorhabdus stylifer ( = Rhabdosphaera stylifer). They mentioned that they had been unable to find any coccospheres constructed exclusively of these discoliths. However, in sediments recovered on Leg 4, the abundances of "Discolithina" phaseola and Aspidorhabdus stylifer appear to vary independently. For this reason the two forms are recorded separately on the distribution charts.

Family CALCiOSOLENIACEAE Kamptner, 1937

Genus Scapholithus Deflandre, 1954

Scapholithus fossilis Deflandre:

Isolated scapholiths occur in Pleistocene samples.

Family CERATOLITHACEAE Norris, 1965

Genus Ceratolithus Kamptner, 1950

Ceratolithus cristatus Kamptner:

The abundance of this species is highly variable in Pliocene and Pleistocene samples.

Ceratolithus rugosus Bukry and Bramlette:

More heavily constructed than $C$. cristatus, $C$. rugosus appears to be the direct ancestor of the former. The base of the range of $C$. rugosus might be useful as a marker for the base of the Pliocene.

Ceratolithus tricorniculatus Gartner:

Emended by Bukry and Bramlette (1969) to include all forms which are not illumined when lying flat between crossed polarizers. This is the earliest species of the genus, found in the Late Miocene and Early Pliocene.

Family DISCO ASTER ACEAE Tan Sin Hok, 1927 


\section{Genus Discoaster Tan Sin Hok, 1927}

Discoaster aster Bramlette and Riedel:

This is used here as a general term to include all nondescript discoasters with thick blunt arms.

Discoaster barbadiensis Tan Sin Hok:

This species is among the most resistant nannofossils. In the Middle Eocene radiolarian ooze of Site 29 , this is often the only calcareous object which has escaped solution.

Discoaster saipanensis Bramlette and Riedel:

This species has its earliest occurrence in the middle Eocene. The levels of extinction of $D$. saipanensis and $D$. barbadiensis are very close together, and approximate the Priabonian-Lattorfian boundary.

Discoaster ornatus Stradner:

This species, which has a range probably restricted to the Discoaster sublodoensis Zone, is one of the few asteroliths found in the radiolarian ooze at Site 29. It is restricted to the lower part of the Middle Eocene radiolarian ooze section.

Discoaster gemmifer Stradner:

An asterolith species found only in the Middle and Late Eocene; it is rare at Site 28.

Discoaster tani nodifer Bramlette and Riedel:

The presence of this species in the Eocene sediments from Site 28 suggests that the age is Middle or Late Eocene. It also occurs in the sediments recovered deep in the hole at Site 27, where its pattern of abundance resembles that in the basal portion of the Oceanic Formation of Barbados.

Discoaster deflandrei Bramlette and Riedel:

This long ranging species is most abundant in the Lower Miocene. Its occurrence in the Discoaster kugleri Zone at Site 30 is anomalous and probably due to reworking.

Discoaster saundersi Hay:

This species is restricted to the Late Oligocene and Early Miocene. Its range in sediments recovered on Leg 4 confirms that found in the Trinidad section.

Discoaster trinidadensis Hay:

This species was found at Holes 29B, 30 and 31 . Its range may be extended to include the latest Oligocene as well as the Early Miocene.

Discoaster nephados Hay:

Asteroliths of this species are abundant in the latest Oligocene and Early Miocene. They constitute a major element of the assemblage in cores from the bottom of the hole at Site 31 .

Discoaster aulakos Gartner:

This species occurs in the Early Miocene at Sites 30 and 31 , and appears to be restricted to that interval.
Discoaster dilatus Hay:

This is a general term used for asteroliths with six broad arms which flare distally. Its range is extensive, and the species has little stratigraphic value.

Discoaster lidzi Hay:

This is a Late Oligocene derivative of Discoaster deflandrei, and it is very distinctive. Its range is short, restricted to the Late Oligocene, but overlapping at Site 31 with that of Triquetrorhabdulus carinatus.

Discoaster woodringi Bramlette and Riedel:

This taxon is used for six-rayed asteroliths with short stubby arms. It has little stratigraphic value.

Discoaster druggi Bramlette and Wilcoxon (=Discoaster extensus Bramlette and Wilcoxon, non Hay):

No typical specimens of this species were found, but some asteroliths which appear to be closely related are cited on the distribution charts as Discoaster cf. druggi.

Discoaster extensus Hay:

This taxon was proposed to include the less distinctive members of the asterolith group with six parallel-sided rays which bifurcate at the tips. Its range is from early Middle Miocene to Late Pliocene.

Discoaster variabilis Martini and Bramlette:

This is a distinctive species belonging to the same group as Discoaster extensus. $D$. variabilis is distinguished by an elaborate central knob, and appears to be restricted to the Middle and Late Miocene.

Discoaster phyllodus Hay:

This species, previously known only from the late Middle Miocene of Trinidad, was found in the Late Miocene and Early Pliocene at Site 25.

Discoaster exilis Martini and Bramlette: Specimens which closely resemble the type are restricted to a short range in the Middle Miocene.

Discoaster hamatus Martini and Bramlette: Middle Miocene specimens of this species have 5 rays, Late Miocene specimens 6 rays. The interval through which 5- and 6-rayed species occur together is rather short, probably only the base of the Globorotalia acostaensis Zone.

Discoaster brouweri Tan Sin Hok:

A large number of forms have been traditionally placed in this taxon. Bramlette and Riedel (1954) emended the definition of the species to include forms with 3 to 6 long delicate arms. The type illustrated by Tan Sin Hok, however, was a six-rayed form with blunt-tipped cylindrical arms. Tan Sin Hok (1927) described a three-rayed form as Discoaster triradiatus, but this name has rarely, if ever, been used since. Gartner (1967) described a subspecies of $D$. brouweri and another species, $D$. calcaris, which is closely related and is here regarded as a subspecies. Kamptner (1967) described four- and five-rayed forms of the $D$. brouweri complex. These are here 
regarded as subspecies. The taxon $D$. brouweri is used on the distribution charts only to indicate those specimens which cannot be identified more accurately, or which resemble Tan Sin Hok's poorly preserved specimen. The following subspecies are recognized:

Discoaster brouweri rutellus Gartner:

These are six-rayed forms with a blade-like wedge on the concave side of each ray tip. Most well preserved specimens of six-rayed $D$. brouweri belong here.

Discoaster brouweri calcaris Gartner (=Discoaster calcaris Gartner, 1967, p. 2, Plate 2, Figures 1, 2 and 3): Six-rayed forms with delicate rays bifurcating asymmetrically at the tips. This is a specialized form probably restricted to the late Middle and Late Miocene.

Discoaster brouweri tridenus Kamptner (= Discoaster tridenus Kamptner, 1967, p. 166-167, Figure 30):

These are five-rayed asteroliths, found in Middle Miocene through Late Pliocene samples, but most abundant in the Late Miocene and Early Pliocene.

Discoaster brouweri tamalis Kamptner (= Discoaster tamalis Kamptner, 1967, p. 166, Figure 28):

These are four-rayed asteroliths, the rays being at right angles to each other, found only in the Pliocene, and abundant in the middle Pliocene.

Discoaster brouweri triradiatus Tan Sin Hok (= Discoaster triradiatus Tan Sin Hok, 1927, p. 417):

These three-rayed asteroliths are found in the Upper Miocene and Pliocene.

Discoaster pentaradiatus Tan Sin Hok:

The first occurrence of this species is in the upper part of the Discoaster hamatus Zone, and its extinction level is immediately below that of Discoaster brouweri.

Discoaster quinqueramus Gartner (1969, p. 598, Plate 1, Figures 6 and 7):

This is a small five-rayed species with a distinctive ornate knob in the center. It is found only in Laté Miocene and Early to Middle Pliocene deposits.

Discoaster asymmetricus Gartner (1969, p. 598, Plate 1, Figures 1, 2 and 3):

This species is similar to $D$. brouweri tridenus, but the five rays are asymmetrical. It is restricted to the Lower and Middle Pliocene.

Discoaster surculus Martini and Bramlette:

This distinctive species has the base of its range in the Late Miocene, and becomes extinct in the Late Pliocene.

Discoaster kugleri Martini and Bramlette:

Observations on samples from Leg 4 show that this species is generally rare in oceanic sediments. It appears to be restricted to a short interval in the Middle Miocene.
Discoaster bollii Martini and Bramlette:

This species or forms very close to it occur in the Discoaster kugleri, Discoaster exilis, and Helicopontosphaera ampliaperta Zones at Holes 30, 31 and $29 \mathrm{~B}$, respectively. It may be possible to distinguish subspecies of greater stratigraphic value with further study, but for the present, the range of the species must be regarded as late Early Miocene through Middle Miocene.

Discoaster perplexus Bramlette and Riedel:

This unusual species, which had its origin in the Middle Miocene and is probably still living, is represented by isolated asteroliths in some samples.

Genus Catinaster Martini and Bramlette

Catinaster calyculus Martini and Bramlette:

Rare specimens were found in the Discoaster hamatus Zone at Holes 23 and 25A.

Genus Ellipsodiscoaster Boudreaux and Hay

Ellipsodiscoaster lidzi Boudreaux and Hay (1969, p. 288, Plate 10, Figures 4 through 15):

This species is a rare component of Late Pleistocene and Recent assemblages.

Family SPHENOLIT HACEAE Deflandre, 1952

Genus Sphenolithus Deflandre, 1952

Sphenolithus moriformis (Bronnimann and Stradner) (ex Nannoturbella):

This term is used for robust beehive-shaped sphenoliths. Bramlette and Wilcoxon (1967) suggested that all of the less distinctive sphenoliths could be lumped together, but as their occurrences differ, they are recorded as separate species here.

Sphenolithus pacificus Martini:

This term is used here for the smaller, more delicate beehive-shaped sphenoliths. Forms of this type are particularly characteristic of the Late Oligocene and Lower Miocene.

Sphenolithus ciperoensis Bramlette and Wilcoxon:

This is a small but distinctive sphenolith distinguished by the interference cross in the base. The two sides of the cross do not meet when the specimen is viewed between crossed polarizers with its long axis $45^{\circ}$ to the planes of polarization.

Sphenolithus distentus Martini (ex Furcatolithus):

This sphenolith species is distinguished by having an incomplete cross in the base when observed between crossed polarizers with the long axis inclined $45^{\circ}$ to the planes of polarization.

Sphenolithus heteromorphus Deflandre:

This is a large robust sphenolith with a long spine. This species is evidently much more resistant to solution than $S$. ciperoensis or $S$. distentus. The latter 
species are very rare in Leg 4 samples, but $S$. heteromorphus is present in abundance at the appropriate stratigraphic levels.

Sphenolithus abies Deflandre:

A less distinctive species with the shape of an elongate beehive, $S$. abies is the Late Miocene - Pliocene descendant of $S$. pacificus. The extinction level of $S$. abies is a useful stratigraphic horizon in some areas, but the species seems to be susceptible to solution, so that it is wholly lacking in some sections where it should occur (viz. Site 25).

\section{Family TRIQUETRORHA BDULACEAE Lipps, 1969}

\section{Genus Triquetrorhabdulus Martini, 1965}

Triquetrorhabdulus carinatus Martini:

This species occurs in great numbers in Late Oligocene - Early Miocene samples from several sites. It is very distinctive, and an extremely useful stratigraphic marker.

Triquetrorhabdulus rugosus Bramlette and Wilcoxon: Well preserved specimens of this species occur in samples from Core 2, Hole 29B. A more extensive suite of specimens was found in the Discoaster kugleri Zone at Site 30, but the preservation in all samples is poor.

Family MICR OR HA BD ULA CEAE Deflandre, 1963

$$
\text { Genus Microrhabdulus Deflandre, } 1959
$$

Microrhabdulus decoratus Deflandre:

This ubiquitous Upper Cretaceous nannofossil was found only in the deeper part of the hole drilled at Site 28 .

\section{INCERTAE SEDIS}

\section{Genus Micula Vekshina, 1959}

Micula staurophora (Gardet) (ex Discoaster):

Specimens were found in the deeper part of Hole 28.

\section{ZONATION}

The zonation employed here is adapted from that of Hay et al. (1967), Bramlette and Wilcoxon (1967), Gartner (1969), and Boudreaux and Hay (1969). TextFigure 1 presents the zonal terms used, along with the criteria used to determine the zone limits. Zone limits have been defined by Hay et al., Gartner, and Boudreaux and Hay as the first or last occurrence of a taxon in each case. Bramlette and Wilcoxon did not define the limits of the zones they named. The spirit of their classification has been followed whenever possible, but in one instance (upper limit of the Sphenolithus ciperoensis Zone) a species not mentioned by Bramlette and Wilcoxon has been utilized (top of Discoaster lidzi).
One new unit is suggested on the text-figure, the Discoaster exilis Zone, defined as the interval from the base of the range of Discoaster exilis to the base of the range of Discoaster kugleri. This effectively fills in that portion of the Middle Miocene not named by Bramlette and Wilcoxon.

\section{DISCUSSION OF CALCAREOUS NANNOPLANKTON FOSSILS AT THE DRILLED SITES}

\section{Site 23 (lat $6^{\circ} 08.75^{\prime} \mathrm{S}$, long $31^{\circ} 02.06^{\prime} \mathrm{W}$ )}

At this site, in water 16,664 feet (5079 meters) deep, only the surficial sediments contain abundant nannofossils. Isolated specimens and sparse, poorly preserved assemblages were encountered at a few deeper levels, aiding in the determination of the age of the sediment.

Core 1 , which recovered 24 feet ( 7.3 meters) of the surficial deposits, contains mixed Pleistocene and Pliocene assemblages in states of preservation varying from good to poor. Most of the samples contained corroded coccoliths. The distribution of species is summarized in Table 1. The assemblages are obviously mixed, with a number of species known to have mutually exclusive ranges occurring together in some samples. The upper part of Section 1 is probably above the base of the range of Gephyrocapsa oceanica as that species occurs in considerable abundance. The highest occurrence of Discoaster brouweri s. 1. lies between 111 and 144 centimeters in Section 2. Discoaster pentaradiatus, which consistently disappears before $D$. brouweri, occurs at the base of Section 3. The core catcher sample contains a distinctly younger assemblage than those in the lower parts of the core; this probably indicates that the core catcher retained material which slumped into the hole, or that it resampled a higher level during recovery. The top of the range of Discoaster brouweri in the lower part of Section 2 may approximate the Pliocene-Pleistocene boundary.

The bit plug removed before taking the second core contained about $1 \mathrm{cc}$ of sediment, which yielded an assemblage with a few discoasters and a very few heavily corroded coccolith fragments representing the following species: Discoaster variabilis, $D$. brouweri, D. hamatus, D. bollii, D. exilis?,D. kugleri?, Catinaster calyculus, Reticulofenestra pseudoumbilica? and Cyclococcolithus leptoporus?. Specimens are too rare to permit an estimate of relative abundances. The almost complete absence of coccoliths is striking; only the more corrosion-resistant discoasters and related forms have been preserved, indicating deposition well into the zone of calcium carbonate compensation. The discoasters referred questionably to $D$. exilis and $D$. kugleri are poorly preserved, and might have been reworked from older deposits or transported into the area. The rest of the assemblage belongs to the Discoaster hamatus Zone (uppermost Middle Miocene). Presumably the bit 
TABLE 1

Distribution of Calcareous Nannofossils in Core 1, Site 23.

\begin{tabular}{|c|c|c|c|c|c|c|c|c|c|c|}
\hline \multicolumn{10}{|c|}{ PLEISTOCENE } & Age \\
\hline \multicolumn{10}{|c|}{ Gephyrocapsa oceanica } & Zone \\
\hline \multicolumn{10}{|c|}{$0-9.1$} & Depth Below Sea Floor in Meters \\
\hline \multicolumn{10}{|c|}{1} & Core Number \\
\hline \multicolumn{3}{|c|}{1} & \multicolumn{4}{|c|}{2} & \multicolumn{3}{|c|}{3} & Section Number \\
\hline 80 & 87 & 123 & 20 & 111 & 144 & 150 & 10 & 144 & $\mathrm{CC}$ & Depth in Section in Centimeters \\
\hline \multirow[t]{2}{*}{0} & $?$ & 1 & & $?$ & & 0 & 1 & 1 & $?$ & Gephyrocapsa oceanica \\
\hline & & & & & & & 1 & 1 & $?$ & Gephyrocapsa aperta \\
\hline \multirow[t]{4}{*}{1} & & 1 & & & 0 & 0 & 0 & 0 & 0 & Gephyrocapsa caribbeanica \\
\hline & -1 & 0 & & & -2 & & -1 & & & Pseudoemiliania lacunosa (circular) \\
\hline & 0 & 0 & & -1 & 0 & 0 & 0 & -1 & -1 & Pseudoemiliania lacunosa (elliptical) \\
\hline & & & & & & -2 & -2 & & -1 & Coccolithus pelagicus \\
\hline-2 & -2 & 0 & & -1 & -1 & -1 & -1 & & -1 & Cyclococcolithus leptoporus \\
\hline \multirow[t]{2}{*}{-2} & & & & -1 & -1 & -1 & -1 & -1 & -1 & Umbilicosphaera mirabilis \\
\hline & -2 & & & & & -2 & & & & Cyclolithella annula \\
\hline \multirow[t]{13}{*}{-2} & & & & & -1 & 0 & -1 & & & Helicopontosphaera kamptneri \\
\hline & & & & & & -2 & & & & Helicopontosphaera wallichi \\
\hline & & & & & & -2 & & & & Helicopontosphaera $\mathrm{cf}$ seminulum \\
\hline & & & & & & -2 & & & & Pontosphaera scutellum \\
\hline & & & & & & -2 & & & & Pontosphaera discopora \\
\hline & & & & & -1 & -1 & -1 & & -1 & "Discolithina" phaseola \\
\hline & & & & & -1 & & -1 & & -1 & Aspidorhabdus stylifer \\
\hline & & & & & -2 & -2 & & -1 & & Ceratolithus cristatus \\
\hline & & & & & -1 & -1 & -1 & & & Discoaster brouweri s.1. \\
\hline & & & & & & -2 & & & & Discoaster pentaradiatus \\
\hline & & & & & & $?$ & & & & Discoaster surculus \\
\hline & & & & & & -2 & & & & "Discoaster aster" \\
\hline & & & & & & -2 & & & & Sphenolithus abies \\
\hline
\end{tabular}


plug material represents a sample from the sediment immediately superjacent to Core 2 (about 175 feet 53 meters - beneath the sea floor).

A sample from 65 centimeters in Section 1 of Core 2 contains a few asteroliths: Discoaster brouweri, $D$. variabilis, and $D$. trinidadensis? The age of the assemblage cannot be determined with precision, but it is Middle Miocene.

Core 3 is barren of calcareous nannoplankton except for the core catcher sample which contained a very few specimens referable to Coccolithus pelagicus and $S c a-$ pholithus fossilis. No age determination is possible.

Core 4, which is 369 to 399 feet (112 to 121 meters) below sea floor, is entirely barren.

Core 5, which is 399 to 429 feet (121 to 130 meters) below sea floor, recovered two feet of clay with sand layers. The clay at 23 centimeters in Section 1 is barren. The uppermost sand layer, at 4 centimeters in Section 1 contains a very few nannofossil specimens: Coccolithus pelagicus and Sphenolithus abies. The lower sand, at 47 centimeters in Section 1, contains a poor assemblage with: Cyclococcolithus floridanus, Reticulofenestra bisecta, Discoaster saundersi and Triquetrorhabdulus carinatus. The assemblage is referable to the Triquetrorhabdulus carinatus Zone (lowermost Lower Miocene).

Only a core catcher sample was recovered from Core 6 , from 429 to 459 feet (130 to 140 meters) below sea floor. This contains a more diverse, slightly better preserved nannofossil assemblage than Core 5: Discoaster saundersi, D. nephados, D. woodringi, Sphenolithus abies, Coccolithus pelagicus, Cyclococcolithus floridanus, and Triquetrorhabdulus carinatus. This is also referable to the Triquetrorhabdulus carinatus Zone (lowermost Lower Miocene).

All samples from this site show heavy corrosion of the coccoliths, with the exception of some Pleistocene forms from the surficial layers, indicating deposition within the zone of calcium carbonate compensation from at least the Miocene until the Pleistocene.

\section{Site 24 (lat. $6^{\circ} 16.74^{\prime} \mathrm{S}$, long. $30^{\circ} 53.18^{\prime} \mathrm{W}$ )}

This site, about 10 miles SE of Site 23, was drilled in a water depth of 16,889 feet (5148 meters) in an attempt to sample the sediments deeper than the basalt encountered at Site 23. Two holes were attempted.

In the first hole, four 30-foot cores were cut between 650 and 770 feet (198 and 235 meters) below the sea floor. Recovery was slight to nil in all except the deepest of these; the fourth core recovered 16 feet (4.8 meters) of sediment. The deposits consist of clays and sands, The clays are barren of calcareous nannofossils, but the sandy layers contain assemblages in varying states of preservation. The distribution of species is indicated in Table 2. All of these assemblages are assignable to the Triquetrorhabdulus carinatus Zone (lowermost Lower Miocene).

In the second hole, four cores were cut between 1650 and 1832 feet (503 and 558 meters) below the sea floor, and small amounts of sediment were recovered in each. The sediments are green to black silts or muds, and they are completely devoid of calcareous nannoplankton fossils.

\section{Site 25 (lat. $0^{\circ} 31.00^{\prime} \mathrm{S}$, long. $39^{\circ} 14.40^{\prime} \mathrm{W}$ )}

This site is on a narrow, elongate ridge off Fortalega, Brazil, in a water depth of about 6286 feet (1916 meters). Two cores had been taken in this area by the Vema during the site survey, and two holes were drilled by the Glomar Challenger.

Vema Core 26-102 was taken at lat. $00^{\circ} 23^{\prime}$ S, long. $39^{\circ} 08^{\prime} \mathrm{W}$, and recovered about 774 centimeters of the surficial deposits. Distribution of calcareous nannofossil species in a series of samples from this core is shown in Table 3. The upper 200+ centimeters of the core contains Emiliania huxleyi, and belongs to the uppermost Upper Pleistocene-Recent E. huxleyi Zone. The lower part of the core contains Gephyrocapsa oceanica throughout its length, but Pseudoemiliania lacunosa does not occur in it. The lower part of the core lies within the interval between the highest occurrence of $P$. lacunosa and the lowest occurrence of $E$. huxleyi, i.e. the upper part of the Upper Pleistocene G. oceanica Zone.

Vema Core $26-103$ was taken at lat. $00^{\circ} 29^{\prime} \mathrm{S}$, long. $39^{\circ} 32^{\prime} \mathrm{W}$, and recovered about 1060 centimeters of sediment. Distribution of the calcareous nannoplankton is shown in Table 4. In this core, the upper 100+ centimeters belongs to the $E$. huxleyi Zone, and the lowest sample does not touch the highest occurrence surface of $P$. lacunosa; the entire lower part of this core also belongs to the upper part of the G. oceanica Zone. There is a good correlation of relative abundances of species between these two cores; changes which occur in 26-102 also occur in 26-103 about 100 centimeters higher in the core.

The first drilled hole at Site 25 was an attempt to core the sediment continuously. Nine cores were cut to a depth of 252 feet ( 77 meters) beneath the sea floor, but only the upper four cores provided reasonably good recovery.

Distribution of the calcareous nannofossils in Cores 1 and 2 is shown in Table 5. Pseudoemiliania lacunosa occurs in abundance throughout Cores 1 and 2. Although it had been assumed that coring began at the 
TABLE 2

Distribution of Calcareous Nannofossils in Cores 1 and 4, Site 24

\begin{tabular}{|c|c|c|c|c|}
\hline \multicolumn{4}{|c|}{ LOWER MIOCENE } & Age \\
\hline \multicolumn{4}{|c|}{$\begin{array}{c}\text { Triquetrorhabdulus } \\
\text { carinatus }\end{array}$} & Zone \\
\hline \multicolumn{2}{|c|}{$198.1-207.3$} & \multicolumn{2}{|c|}{$225.6-234.7$} & Depth Below Sea Floor in Meters \\
\hline \multicolumn{2}{|c|}{1} & \multicolumn{2}{|c|}{4} & Barrel Number \\
\hline \multicolumn{2}{|c|}{1} & \multicolumn{2}{|c|}{3} & Section Number \\
\hline \multirow[t]{3}{*}{5} & $\mathrm{CC}$ & 15 & 100 & Depth in Section in Centimeters \\
\hline & & -1 & & Coccolithus pelagicus \\
\hline & 0 & 0 & 0 & Reticulofenestra bisecta \\
\hline \multirow[t]{4}{*}{0} & 0 & 0 & 0 & Cyclococcolithus floridanus \\
\hline & -1 & -2 & & Helicopontosphaera parallela \\
\hline & -2 & & & Discolithina vigintiforata \\
\hline & -1 & -2 & -2 & Discoaster deflandrei \\
\hline-2 & 0 & & & Discoaster saundersi \\
\hline \multirow[t]{4}{*}{-2} & -2 & -2 & -2 & Discoaster woodringi \\
\hline & & -1 & & Sphenolithus moriformis \\
\hline & & 0 & & Sphenolithus pacificus \\
\hline & -2 & & & Sphenolithus ciperoensis \\
\hline-1 & -1 & -2 & -1 & Triquetrorhabdulus carinatus \\
\hline
\end{tabular}


TABLE 3

Distribution of Calcareous Nannoplankton in Vema Core 26-102

\begin{tabular}{|c|c|c|c|c|c|c|c|c|c|c|}
\hline \multicolumn{4}{|c|}{ PLEISTOCENE-RECENT } & \multicolumn{6}{|c|}{ PLEISTOCENE } & Age \\
\hline \multicolumn{4}{|c|}{ Emiliania huxleyi } & \multicolumn{6}{|c|}{ Gephyrocapsa oceanica } & Zone \\
\hline 0 & 50 & 100 & 200 & 300 & 400 & 500 & 605 & 700 & 774 & Depth in Core in Centimeters \\
\hline 3 & 2 & 1 & 0 & & & & & & & Emiliania huxleyi \\
\hline 1 & 1 & 1 & 0 & 1 & 1 & 1 & 1 & 1 & 1 & Gephyrocapsa oceanica \\
\hline & & 1 & 0 & 1 & 1 & 1 & 1 & 1 & 1 & Gephyrocapsa caribbeanica \\
\hline & -1 & & & & & & & & & Cyclolithella annula \\
\hline 1 & 0 & 0 & -1 & 0 & 0 & 0 & 0 & -1 & 0 & Cyclococcolithus leptoporus \\
\hline 0 & -1 & 0 & -1 & 0 & 0 & 0 & 0 & 0 & 0 & Umbilicosphaera mirabilis \\
\hline 0 & 0 & 0 & -1 & 0 & 0 & 0 & 0 & & 0 & Helicopontosphaera kamptneri \\
\hline-1 & -1 & & -1 & -1 & -1 & -1 & & & & Helicopontospheraa wallichi \\
\hline & & & & & -1 & & & & & Pontosphaera scutellum \\
\hline-1 & -1 & & & & & & & & & Pontosphaera discopora \\
\hline & & 0 & & 0 & 0 & 0 & & & & "Discolithina" phaseola \\
\hline-1 & & -1 & -1 & & & 0 & & & & Aspidorhabdus stylifer \\
\hline 0 & & & -1 & & & -2 & & -2 & -1 & Ceratolithus cristatus \\
\hline & & & & 0 & & & & & -1 & Scapholithus fossilis \\
\hline & & & & & -2 & & & & & Discoaster pentaradiatus \\
\hline & & & & & & & -1 & & & Ellipsodiscoaster lidzi \\
\hline
\end{tabular}


TABLE 4

Distribution of Calcareous Nannoplankton in Vema Core 26-103

\begin{tabular}{|c|c|c|c|c|c|c|c|c|c|c|c|c|c|}
\hline \multicolumn{3}{|c|}{$\begin{array}{l}\text { PLEISTOCENE } \\
\text { RECENT }\end{array}$} & \multicolumn{10}{|c|}{ PLEISTOCENE } & Age \\
\hline \multicolumn{3}{|c|}{ Emiliania huxleyi } & \multicolumn{10}{|c|}{ Gephyrocapsa oceanica } & Zone \\
\hline 0 & 50 & 100 & 200 & 300 & 400 & 500 & 600 & 700 & 800 & 900 & 1000 & 1060 & Depth in Core in Centimeters \\
\hline 3 & $?$ & $?$ & & & & & & & & & & & Emiliania huxleyi \\
\hline 1 & 1 & 1 & 1 & 1 & 1 & 1 & 1 & 0 & 0 & 1 & 1 & 0 & Gephyrocapsa oceanica \\
\hline & & & -1 & & & & & & & & & & Gephyrocapsa aperta \\
\hline & & & -1 & -1 & 0 & 0 & 0 & 1 & 1 & 1 & 1 & 1 & Gephyrocapsa caribbeanica \\
\hline & -1 & & 0 & & & & & & & & & & Coccolithus pelagicus \\
\hline & -1 & & 0 & & & & & & & & & & Cyclolithella annula \\
\hline 1 & 1 & 1 & 1 & -1 & 0 & 0 & 0 & 0 & -1 & 0 & 0 & -1 & Cyclococcolithus leptoporus \\
\hline 0 & 0 & 0 & 0 & 0 & 0 & 0 & 0 & 0 & 0 & -1 & & -1 & Umbilicosphaera mirabilis \\
\hline 0 & 0 & 0 & 0 & -1 & -1 & 1 & 1 & 0 & -1 & 0 & 0 & -1 & Helicopontosphaera kamptneri \\
\hline-1 & & & & & & & & -1 & & & & & Helicopontosphaera wallichi \\
\hline & -1 & & & & & & -1 & & & & & & Pontosphaera Discopora \\
\hline 1 & & 1 & & & & 0 & & & 0 & & & & "Discolithina" phaseola \\
\hline 1 & 0 & 0 & 0 & -1 & & 0 & 0 & -1 & -1 & & & & Aspidorhabdus stylifer \\
\hline 0 & & -1 & -1 & -2 & -1 & -1 & & & & & & -2 & Ceratolithus cristatus \\
\hline & & & & -2 & & & & & & & & & Discoaster sp. \\
\hline & $\mathrm{F}$ & & & & & & & -2 & & & & & Discoaster pentaradiatus \\
\hline & & & -2 & & & & & & & & & & Discoaster woodringi \\
\hline-1 & & & -1 & -1 & & & & & & & & & Sphenolithus abies \\
\hline
\end{tabular}


TABLE 5

Distribution of Calcareous Nannofossils in Cores 1 and 2, Site 25

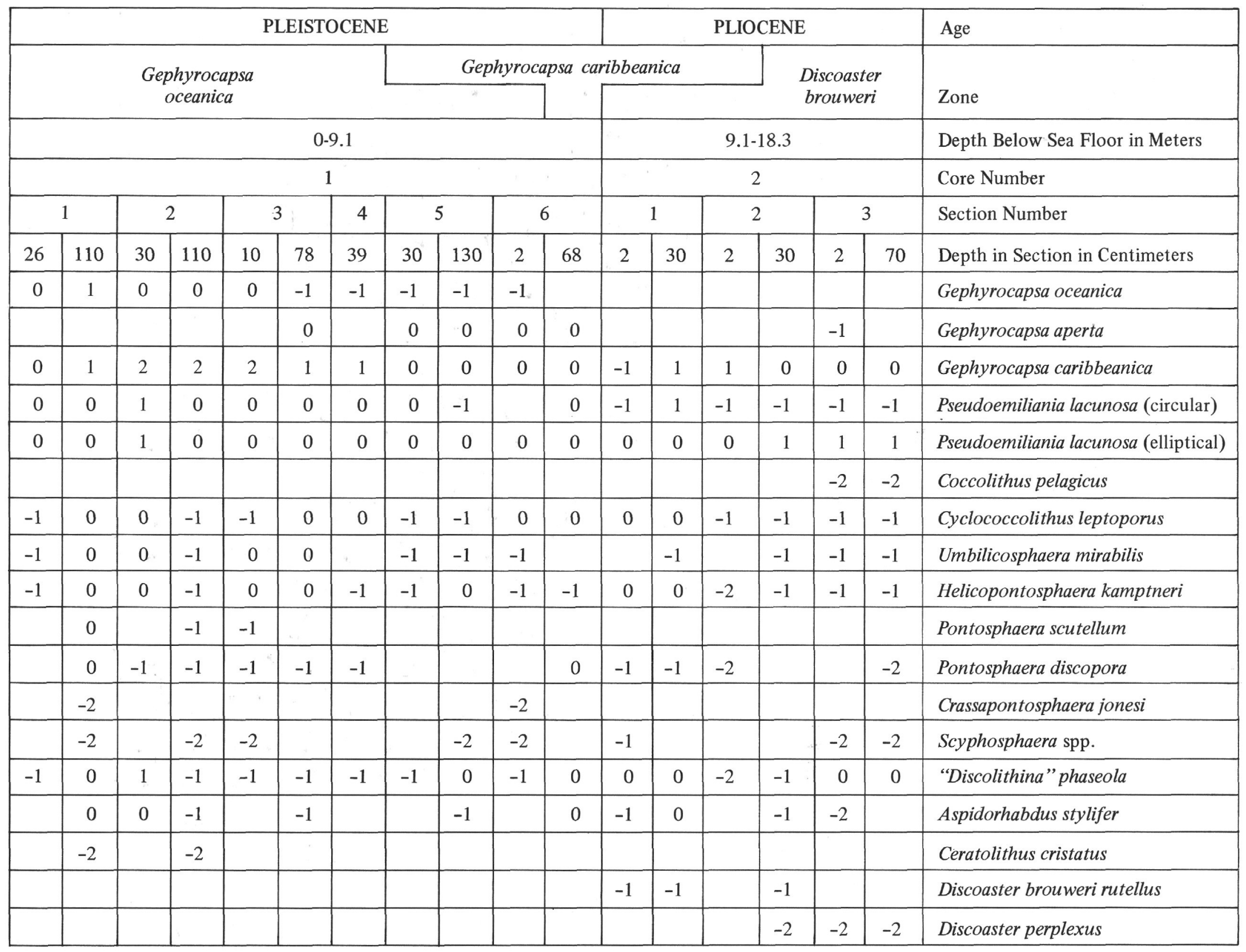


sediment surface, it is obvious that the top of Core 1 is already well below the highest occurrence surface of $P$. lacunosa. Because the Vema cores did not reach this important datum, it may be inferred that more than 35 feet ( 11 meters) of sediment were bypassed before the first drilled core was taken. The lowest occurrence of Gephyrocapsa oceanica is within Section 6 of Core 1; the higher part of Core 1 is assignable to the lower part of Upper Pleistocene G. oceanica Zone. The highest occurrence of Discoaster brouweri is in the top of Core 2. The absence of Discoaster pentaradiatus in Core 2 suggests that the entire core belongs to the interval between the highest occurrence of $D$. pentaradiatus and the highest occurrence of $D$. brouweri, i.e. the upper part of the Upper Pliocene $D$. brouweri Zone. The Gephyrocapsa caribbeanica Zone must be restricted to the base of the lowest section of the first core, and to the unsampled interval between the recovered sediments of Cores 1 and 2 .

There is an abrupt change in calcareous nannoplankton assemblages between Cores 2 and 3 , probably due to poor recovery during the coring operation. Distribution of calcareous nannoplankton fossils in Cores 3 and 4 is shown in Table 6. Discoaster asymmetricus is present in Section 1 of Core 3, and this section probably belongs to the Lower Pliocene $D$. asymmetricus Zone. Ceratolithus rugosus has its lowest occurrence in the upper part of Section 3 of Core 3. Section 2 and the top of Section 3 of Core 3 probably belong to the basal Pliocene $C$. rugosus Zone. The highest occurrence of Discoaster quinqueramus is in the lower part of Section 4 of Core 3, so that the lower part of Section 3 and upper part of Section 4 of Core 3 may be referred to the uppermost Miocene Ceratolithus tricorniculatus Zone. The highest occurrence of Discoaster hamatus is at the top of Section 2 of Core 4; the lower part of Section 4 and all of Sections 5 and 6 of Core 3 and Section 1 of Core 4 belong to the Discoaster quinqueramus Zone (middle Upper Miocene). The specimens of Discoaster hamatus in Core 4 are all six-rayed, indicating the upper part of the $D$. hamatus Zone (basal Upper Miocene).

Core 5 recovered only a core catcher sample with a mixed nannoplankton assemblage containing: Discoaster brouweri s.1., D. extensus, $D$. deflandrei, $D$. divaricatus, $D$. dilatus, $D$. aulakos, $D$. subsurculus, $D$. perplexus, Sphenolithus moriformis, Reticulofenestra pseudoumbilica, Coccolithus pelagicus, Cyclococcolithus leptoporus, and exclusively six-rayed specimens of Discoaster hamatus. This assemblage seems to represent a mixture of species from the basal Upper Miocene and middle Middle Miocene.

A second hole at the same site attempted to continuously core the sediments between 162 and 252 feet (49 and 77 meters) below the sea floor. Only the uppermost core provided any section; the distribution of calcareous nannoplankton in the 8 feet of sediment which were recovered is presented in Table 7 . The entire column recovered in Core 1 represents the Discoaster hamatus Zone.

\section{Site 26 (lat. $10^{\circ} 53.55^{\prime} \mathrm{N}$, long. $44^{\circ} 02.57^{\prime} \mathrm{W}$ )}

At this site, in the Vema Fracture Zone, water depth was 16,954 feet (5169 meters). Spaced coring was attempted to determine the nature and age of the sediments. The distribution of calcareous nannoplankton in the recovered core sections is indicated in Table 8. Gephyrocapsa oceanica occurs throughout the entire sequence, and all of the sediment cored, between 315 and 1586 feet ( 96 and 483 meters) below the sea floor is assignable to the $G$. oceanica Zone (Upper Pleistocene). This interval is best subdivided by the highest occurrence surface of Pseudoemiliania lacunosa, which is between Cores 3 and 4 between 782 and 1344 feet (238 and 409 meters) below the sea floor. The dominance of the circular over oval form of $P$. lacunosa in the higher part of that species' range is striking, and may be a useful criterion for further subdivision of the interval.

Assemblages of calcareous nannoplankton are sparse to poor throughout the recovered sediments, but only a few samples are completely barren. The flood of terrigenous material from the Amazon dilutes the assemblages by several orders of magnitude. Reworked discoasters are present in the upper part of Core 1; they indicate a Pliocene source for some of the material near the surface.

\section{Site 27 (lat. $15^{\circ} 51.39^{\prime} \mathrm{N}$, long. $56^{\circ} 52.76^{\prime} \mathrm{W}$ )}

This site, about 250 miles NE of Barbados, had a water depth of 17,223 feet (5251 meters). A surface core was taken by the Vema during the site survey, and two holes were drilled by the Glomar Challenger.

Vema Core $26-113$, taken at lat. $15^{\circ} 48^{\prime} \mathrm{N}$ and long. $56^{\circ}$ $53^{\prime} \mathrm{W}$, contained a useful assemblage of calcareous nannofossils at 300 centimeters, but only very poor assemblages were obtained from samples at 150, 280, 400,500 , and 610 centimeters. A sample from 10 centimeters below the top of the core was devoid of calcareous nannofossils. The assemblage at 300 centimeters shows signs of solution, but the following species are present: Gephyrocapsa oceanica, Pseudoemiliania lacunosa (circular), Cyclococcolithus leptoporus, Helicopontosphaera kamptneri, and Ceratolithus cristatus. These permit an assignment of the sample to the lower part of the G. oceanica Zone (Upper Pleistocene). It is evident that the sediments were deposited deep within the zone of calcium carbonate compensation. 
TABLE 6

Distribution of Calcareous Nannofossils in Cores 3 and 4, Site 25

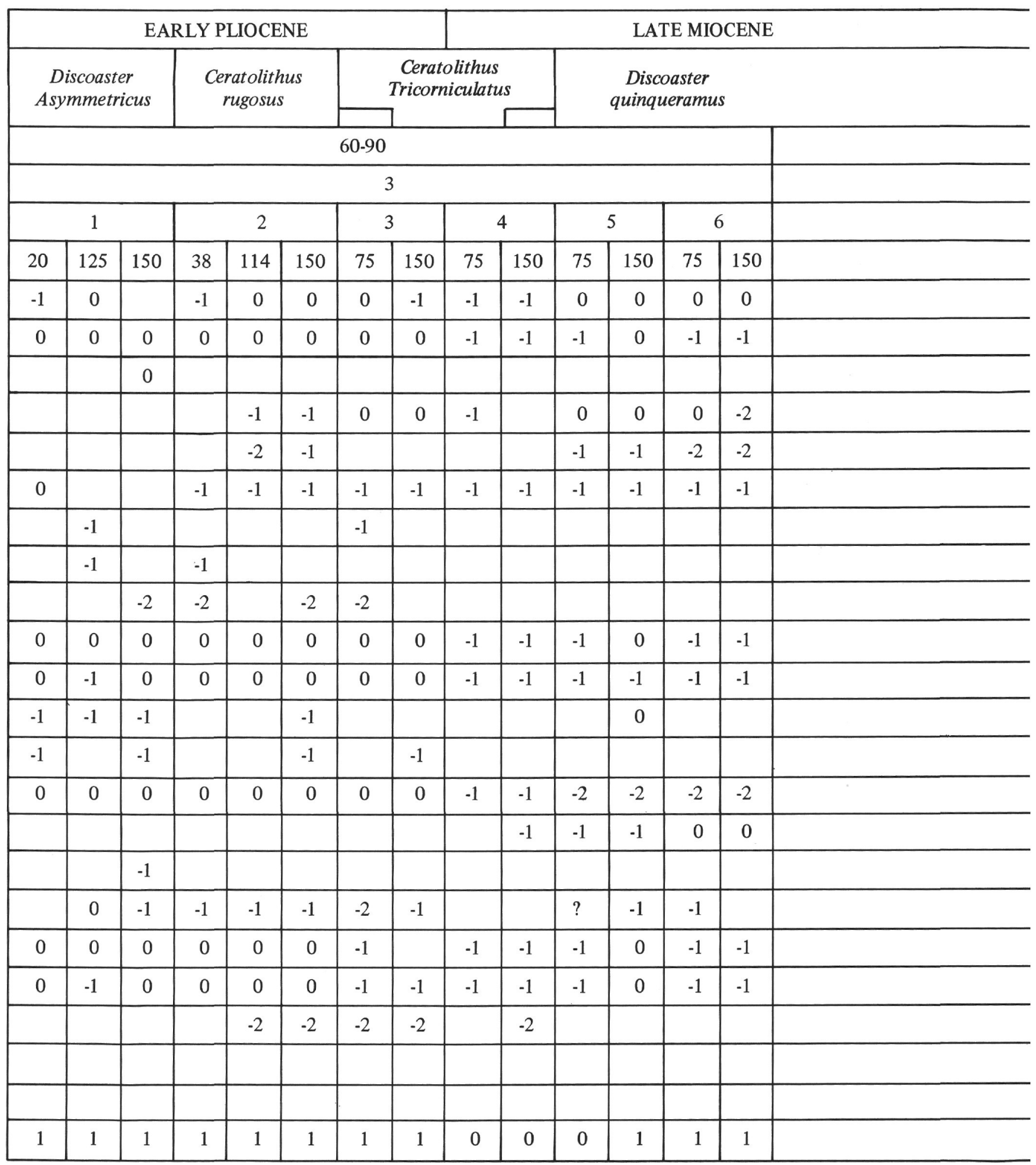




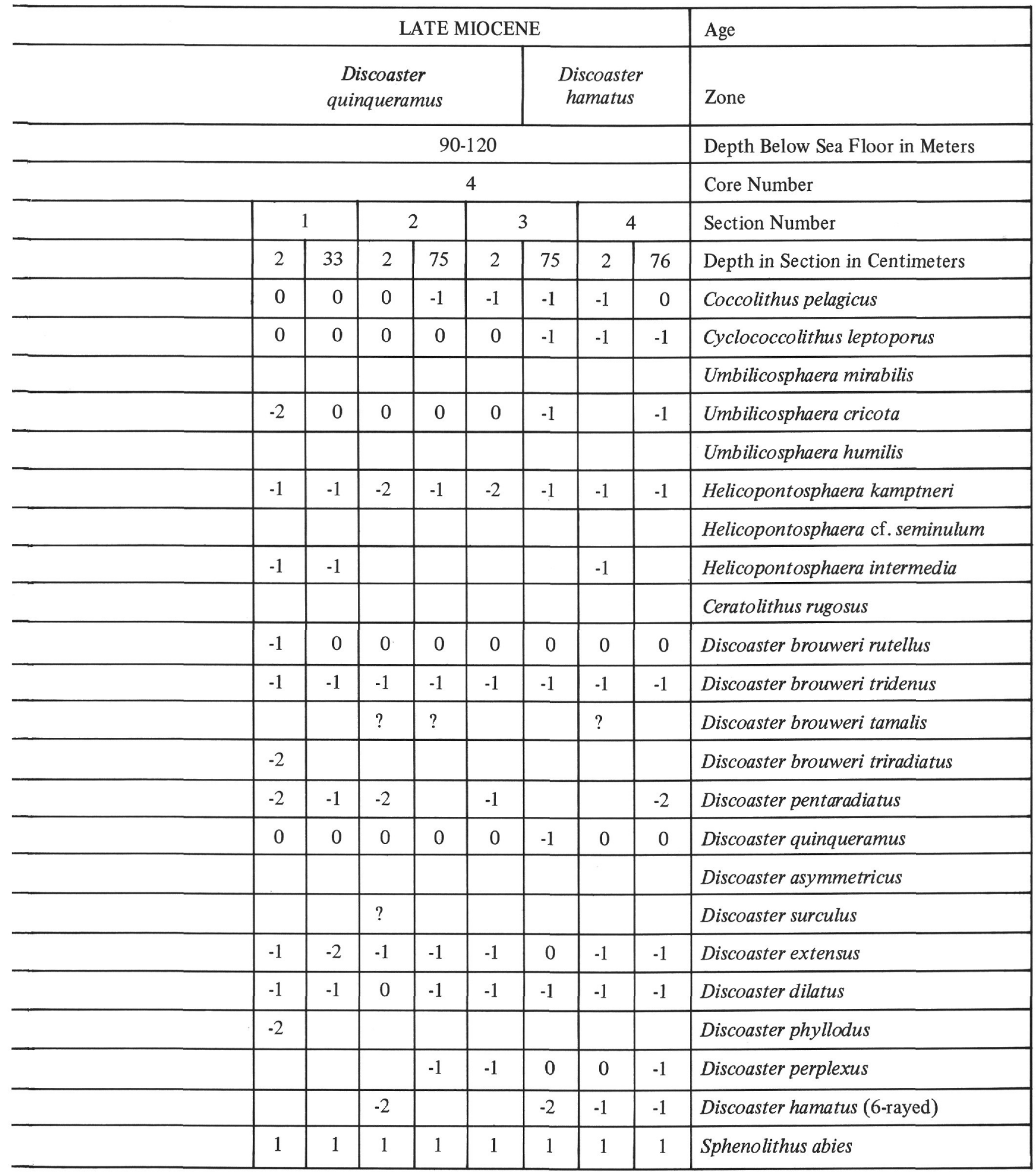


TABLE 7

Distribution of Calcareous Nannofossils in Core 1, Site 25A

\begin{tabular}{|c|c|c|c|c|}
\hline \multicolumn{4}{|c|}{ LATE MIOCENE } & Age \\
\hline \multicolumn{4}{|c|}{$\begin{array}{c}\text { Discoaster } \\
\text { hamatus }\end{array}$} & Zone \\
\hline \multicolumn{4}{|c|}{ 49.4-58.5 } & Depth Below Sea Floor in Meters \\
\hline \multicolumn{4}{|c|}{1} & Core Number \\
\hline \multicolumn{2}{|c|}{1} & \multicolumn{2}{|c|}{2} & Section Number \\
\hline 4 & 84 & 75 & 150 & Depth in Section in Centimeters \\
\hline-1 & 0 & 0 & 0 & Coccolithus pelagicus \\
\hline-1 & -1 & -1 & -1 & Reticulofenestra pseudoumbilica \\
\hline-1 & -1 & -1 & -1 & Cyclococcolithus leptoporus \\
\hline-2 & -1 & -2 & & Helicopontosphaera kamptneri \\
\hline 0 & 0 & 0 & 0 & Discoaster brouweri rutellus \\
\hline 0 & 0 & 0 & 0 & Discoaster brouweri tridenus \\
\hline-2 & 0 & 0 & & Discoaster pentaradiatus \\
\hline-1 & -1 & -1 & 0 & Discoaster extensus \\
\hline-1 & 0 & 0 & 0 & Discoaster dilatus \\
\hline-2 & & -2 & & Discoaster perplexus \\
\hline & $?$ & $?$ & -1 & Discoaster challengeri \\
\hline-1 & -1 & -1 & -1 & Discoaster hamatus (6-rayed) \\
\hline-2 & & & -1 & Discoaster hamatus (5-rayed) \\
\hline-2 & & & & Discoaster cf. exilis \\
\hline & -2 & -2 & & Discoaster deflandrei \\
\hline & & $?$ & -2 & Catinaster calyculus \\
\hline 0 & 0 & 0 & 0 & Sphenolithus abies \\
\hline
\end{tabular}



TABLE 8

Distribution of Calcareous Nannofossils in Cores 1-5, Site 26

\begin{tabular}{|c|c|c|c|c|c|c|c|c|c|c|c|c|c|c|c|c|c|}
\hline \multicolumn{17}{|c|}{ PLEISTOCENE } & \\
\hline \multicolumn{17}{|c|}{ Gephyrocapsa oceanica } & \\
\hline \multicolumn{8}{|c|}{$96.0-105.2$} & \multicolumn{2}{|c|}{$105.2-114.3$} & \multicolumn{3}{|c|}{$229.2-238.4$} & \multicolumn{2}{|c|}{$400.8-410.0$} & & & \\
\hline \multicolumn{8}{|c|}{1} & \multicolumn{2}{|c|}{2} & \multicolumn{3}{|c|}{3} & \multicolumn{2}{|c|}{4} & & & \\
\hline \multicolumn{2}{|c|}{1} & \multicolumn{2}{|c|}{2} & \multicolumn{3}{|c|}{3} & & 1 & 2 & \multicolumn{2}{|c|}{1} & & 1 & & \multicolumn{2}{|c|}{1} & \\
\hline 0 & 150 & 15 & 100 & 1 & 132 & 147 & $\mathrm{CC}$ & 110 & 2 & 143 & 150 & $\mathrm{CC}$ & 150 & $\mathrm{CC}$ & 6 & 100 & \\
\hline \multirow[t]{5}{*}{-1} & -2 & 0 & 0 & 0 & 0 & 0 & -1 & -1 & 0 & -1 & -2 & -2 & -1 & 0 & 0 & 0 & \\
\hline & & -2 & & -2 & & & -2 & -2 & & -2 & -2 & -2 & -1 & -1 & -1 & & \\
\hline & -1 & & & & & & & & & & & -2 & & & & & \\
\hline & & & & & & & & & & & & & & -1 & -1 & -2 & \\
\hline & & & & & & & -2 & & & & & & -2 & -2 & -2 & & \\
\hline \multirow[t]{2}{*}{-2} & & & & & -2 & & & & & & & & & & & & \\
\hline & & & & & -2 & -2 & -2 & -2 & & & & & -2 & & -2 & & \\
\hline-2 & -2 & -2 & & & & & & & -2 & & & & & & & & \\
\hline-2 & -2 & & & & & & & & & & & & & & & & \\
\hline-3 & -3 & & & & & & & & & & & & & & & & \\
\hline \multirow[t]{2}{*}{-3} & -3 & & & & & & & & & & & & & & & & \\
\hline & & & & & & & & & & -2 & & & & & & & \\
\hline
\end{tabular}




\begin{tabular}{|c|c|c|c|c|c|c|}
\hline & & & & & & Age \\
\hline & & & & & & Zone \\
\hline \multicolumn{4}{|c|}{$476.7-483.4$} & & & Depth Below Sea Floor in Meters \\
\hline \multicolumn{4}{|c|}{5} & & & Core Number \\
\hline \multicolumn{2}{|c|}{2} & \multicolumn{2}{|c|}{3} & \multicolumn{2}{|c|}{4} & Section Number \\
\hline 15 & 101 & 45 & 100 & 4 & 24 & Depth in Section in Centimeters \\
\hline 0 & 0 & 0 & 0 & 0 & -2 & Gephyrocapsa oceanica \\
\hline & -1 & -2 & -2 & & & Gephyrocapsa aperta \\
\hline & & & & & & Gephyrocapsa caribbeanica \\
\hline-2 & & & -2 & & & Pseudoumbilica lacunosa (circular) \\
\hline & -2 & -2 & -2 & & & Pseudoemiliania lacunosa (elliptical) \\
\hline & & -2 & & -2 & & Cyclococcolithus leptoporus \\
\hline & & -2 & -2 & & & Umbilicosphaera mirabilis \\
\hline & & -2 & & -2 & & Helicopontosphaera kamptneri \\
\hline & & & & & & Ceratolithus cristatus \\
\hline & & & & & & Discoaster brouweri s.l. \\
\hline & & & & & & Discoaster pentaradiatus \\
\hline & & & & & & Sphenolithus abies \\
\hline
\end{tabular}


Cores were spaced at intervals through the first drilled hole to determine the history of the site. The first core -275 to 305 feet ( 83 to 92 meters) below the sea floor-and second core-462 to 492 feet (140 to 149 meters) below the sea floor-were found to be completely barren of calcareous nannofossils. Poor assemblages were obtained in Cores 3 and 4-722 to 817 feet (235 to 249 meters) below the sea floor, and better assemblages were found in Core 5-1210 to 1240 feet (368 to 377 meters) below the sea floor. The distribution of calcareous nannofossils in these core barrels is indicated in Table 9. Triquetrorhabdulus carinatus occurs in all three cores, but Sphenolithus ciperoensis is present only in assemblages from Core 5 . Because the highest occurrence of $S$. ciperoensis is a useful criterion for subdividing the $T$. carinatus zone, the presence of the former species in Core 5 and its absence in Cores 3 and 4 is significant. Cores 3 and 4 can be assigned to the upper part of the $T$. carinatus Zone (basal Lower Miocene); Core 5 contains Discoaster lidzi and belongs to the Sphenolithus ciperoensis Zone (Late Oligocene).

Cores 6 and 7 provided poor to fair assemblages of calcareous nannofossils (see Table 10). Coccoliths in these assemblages generally show signs of solution, indicating deposition in the lower part of the zone of calcium carbonate compensation. The species present are typical for an Upper Eocene assemblage, but more precise age determination is not possible. The similarity of the assemblages to those of the lower part of the Oceanic Formation of Barbados is striking (see Hay et al., 1967, Figure 8).

In the second hole drilled at this site, cores were cut between 83 and 113 feet ( 25 and 34 meters) and continuously between 147 and 267 feet (45 and 81 meters) beneath the sea floor. Examination of 43 samples spaced through the recovered cores revealed that the entire sequence is barren of calcareous nannofossils, and was deposited below the calcium carbonate compensation depth.

\section{Site 28 (lat. $20^{\circ} 35.19^{\prime} \mathrm{N}$, long. $65^{\circ} 37.33^{\prime} \mathrm{W}$ )}

This site was located in a water depth of 18,109 feet (5521 meters). Cores were cut at intervals between 194 and 1326 feet (59 and 404 meters) beneath the sea floor.

The first core was taken between 194 and 224 feet ( 59 and 68 meters) beneath the sea floor, but only about $1 \mathrm{cc}$ of sediment was recovered. This was probed for calcareous nannoplankton and found to be barren.

A second core, immediately subjacent to the first, recovered fifteen feet of sediment. Several levels in this core were barren, but a few contained a meager calcareous nannoflora (see Table 11). The assemblage cannot be dated precisely, but is Middle or Upper Eocene.

A third core, which was cut at a deeper level, contained more varied calcareous nannoplankton fossils. Stratigraphic distribution of species is indicated in Table 11. The presence of Chiphragmalithus quadratus, Chiasmolithus gigas, and Discoaster tani nodifer? suggests that the sediment at this depth belongs to the uppermost part of the Chiphragmalithus quadratus Zone or the lowermost part of the Discoaster tani nodifer Zone (upper Middle Eocene).

Core 4 , immediately subjacent to Core 3 , recovered only about $11 / 2$ feet of sediment, which contained an assemblage like that in Core 3.

Core 5 yielded a core catcher sample only, with a calcareous nannoplankton assemblage containing: Coccolithus pelagicus, Coccolithus eopelagicus, Chiasmolithus grandis, Braarudosphaera discula, Discoaster ornatus and Discoaster barbadiensis. Although this core was presumed to have been taken between 774 and 803 feet (235 and 244 meters) beneath the sea floor, the similarity to the material encountered in Core 3 is striking and the possibility of slumping into the hole during coring cannot be ruled out.

No sample was recovered from Core 6 , taken between 904 and 917 feet (275 and 279 meters) beneath the sea floor. A core catcher sample was available from Core 7 , taken immediately subjacent to Core 6 , which is 917 to 927 feet ( 279 to 282 meters) beneath the sea floor. This sample contained a meager assemblage with Coccolithus pelagicus, Discoaster barbadiensis, Discoaster ornatus, Braarudosphaera discula, Micrantholithus flos and Sphenolithus radians. This is also a probable middle Eocene assemblage which might have slumped from higher in the hole during coring.

A watery sample was obtained from the core catcher of Core 8, which is 1132 to 1162 feet (345 to 353 meters) beneath the sea floor, and it contained a few calcareous nannofossils: Discoaster ornatus, Discoaster barbadiensis, Coccolithus pelagicus and Campylosphaera dela. Several chips of rock were obtained in this core catcher sample, and these were examined for content of calcareous nannoplankton. A white claystone contained: Coccolithus pelagicus, C. eopelagicus, Campylosphaera dela, Helicopontosphaera cf. seminulum, Sphenolithus radians, Discoaster barbadiensis and $D$. ornatus; a granular brown chip contained: Campylosphaera dela, Discoaster barbadiensis, and D. ornatus; a green chip contained: Helicopontosphaera cf. seminulum, Sphenolithus radians, Discoaster barbadiensis, and $D$. ornatus; and other green chips were barren. It is evident that these Eocene species occur in several different lithologies, but it is not certain that the 
TABLE 9

Distribution of Calcareous Nannofossils in Cores 3-5, Site 27

\begin{tabular}{|c|c|c|c|c|c|c|c|c|c|c|c|c|c|c|c|}
\hline \multicolumn{8}{|c|}{ EARLY MIOCENE } & \multicolumn{7}{|c|}{ LATE OLIGOCENE } & Age \\
\hline \multicolumn{8}{|c|}{ Triquetrorhabdulus carinatus } & \multicolumn{7}{|c|}{ Sphenolithus ciperoensis } & Zone \\
\hline \multicolumn{3}{|c|}{ 235.3-244.5 } & \multicolumn{5}{|c|}{$244.5-249.0$} & \multicolumn{7}{|c|}{$368.8-378.0$} & Depth Below Sea Floor in Meters \\
\hline \multicolumn{3}{|c|}{3} & \multicolumn{5}{|c|}{4} & \multicolumn{7}{|c|}{5} & Core Number \\
\hline 1 & \multicolumn{2}{|c|}{2} & & \multirow{2}{*}{$\frac{1}{10}$} & \multirow{2}{*}{$\begin{array}{l}2 \\
1\end{array}$} & \multirow{2}{*}{\begin{tabular}{|c|}
3 \\
100 \\
\end{tabular}} & \multirow[b]{2}{*}{$\mathrm{CC}$} & \multirow{2}{*}{$\frac{1}{100}$} & \multicolumn{2}{|c|}{2} & \multicolumn{2}{|c|}{3} & \multicolumn{2}{|c|}{4} & Section Number \\
\hline 4 & 12 & 100 & $\mathrm{CC}$ & & & & & & 15 & 100 & 7 & 100 & 4 & 100 & Depth in Section in Centimeters \\
\hline & & & -2 & -2 & & & -2 & -2 & -2 & -1 & -1 & -1 & -1 & -1 & Reticulofenestra bisecta \\
\hline & & & 0 & & & -2 & -2 & -1 & -1 & -1 & 0 & -1 & -1 & -1 & Coccolithus pelagicus \\
\hline & & & & & & & & & & & & -2 & -1 & -2 & Coccolithus eopelagicus \\
\hline & & & & -2 & & & & & & & & & & & Coccolithus pseudocarteri \\
\hline & -2 & & -2 & & -2 & -2 & & 0 & 0 & 0 & 0 & 0 & -1 & 0 & Cyclococcolithus floridanus \\
\hline & & & -2 & & & & & & & & & & & & Coronocyclus nitescens \\
\hline & & & -2 & & & & & -2 & -2 & -1 & -1 & -1 & -1 & -2 & Helicopontosphaera parallela \\
\hline & & & & & & & & & -2 & & -2 & -2 & -2 & & Helicopontosphaera $\mathrm{cf}$ seminulum \\
\hline & & & & & & & & -2 & -2 & -2 & -1 & -1 & -2 & & Helicopontosphaera compacta \\
\hline & & & & & & & & -2 & & -2 & & -2 & -2 & & Discolithina anisotrema \\
\hline & & & -2 & & & & & -2 & -2 & -2 & -2 & -2 & -2 & -2 & Discolithina vigintiforata \\
\hline & & & -2 & & & -2 & & & & & & & -2 & & Discoaster deflandrei \\
\hline & & $\mathrm{F}$ & -2 & & -2 & & -2 & -2 & -2 & -2 & -1 & -1 & -2 & & Discoaster saundersi \\
\hline & & & & & & & & -2 & & -2 & -2 & -2 & & -2 & Discoaster lidzi \\
\hline & & & -2 & & & & & & & & & & & & Discoaster cf. druggi \\
\hline & & & & & & & & & & & & & -2 & & Discoaster barbadiensis \\
\hline & & & -2 & & & & & -2 & & -2 & -2 & -2 & -2 & & Sphenolithus moriformis \\
\hline & & & -2 & & & -2 & -2 & 0 & 0 & 0 & -1 & -1 & -1 & -1 & Sphenolithus pacificus \\
\hline & & & & & & & & -2 & -2 & -2 & & -2 & & & Sphenolithus ciperoensis \\
\hline & & & -2 & & & & & & & & & & & & Sphenolithus distentus \\
\hline-2 & -2 & -2 & -2 & -2 & -2 & -2 & -1 & & -2 & -2 & -1 & -1 & 0 & -1 & Triquetrorhabdulus carinatus \\
\hline
\end{tabular}


TABLE 10

Distribution of Calcareous Nannofossils in Cores 6 and 7, Site 27

\begin{tabular}{|c|c|c|c|c|l|}
\hline \multicolumn{4}{|c|}{ LATE EOCENE } & Age \\
\hline \multicolumn{5}{|c|}{$\begin{array}{c}\text { Discoaster tani } \\
\text { nodifer }\end{array}$} & Zone \\
\hline \multicolumn{2}{|c|}{$453.5-462.7$} & $473.7-474.6$ & Depth Below Sea Floor in Meters \\
\hline \multicolumn{2}{|c|}{6} & \multicolumn{2}{|c|}{7} & Core Number \\
\hline \multicolumn{2}{|c|}{2} & 3 & 1 & Section Number \\
\hline 41 & 100 & 4 & 10 & 89 & Depth in Section in Centimeters \\
\hline & & & -2 & -2 & Chiasmolithus grandis \\
\hline-2 & -2 & & -2 & -2 & Reticulofenestra umbilica \\
\hline-1 & -1 & & & & Reticulofenestra bisecta \\
\hline 0 & -2 & -2 & -2 & -1 & Coccolithus pelagicus \\
\hline-1 & -2 & & -2 & -2 & Coccolithus eopelagicus \\
\hline & & -2 & & & Helicopontosphaera cf. seminulum \\
\hline-2 & & & & & Discolithina vigintiforata \\
\hline & & & & -2 & Braarudosphaera discula \\
\hline 0 & -2 & -1 & -1 & -1 & Discoaster barbadiensis \\
\hline-1 & -2 & -2 & -2 & -2 & Discoaster saipanensis \\
\hline & & -2 & & & Discoaster deflandrei \\
\hline & & & & -2 & Discoaster tani nodifer \\
\hline
\end{tabular}


TABLE 11

Distribution of Calcareous Nannofossils in Cores 2 and 3, Site 28

\begin{tabular}{|c|c|c|c|c|c|c|c|c|c|c|c|c|c|c|c|c|c|c|}
\hline & & & & & & ATE & OCE & & & & & & & & & & & Age \\
\hline & & & & & Dis & aster & ani & ifer & & & & & & & & & & Zone \\
\hline & $.3-77$ & & & & & 168. & 176 & & & & & & & & & & & Depth Below Sea Floor in Meters \\
\hline & 2 & & & & & & 3 & & & & & & & & & & & Core Number \\
\hline 2 & 3 & 4 & 0 & & 1 & & & & & 3 & & & & & 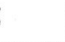 & & & Section Number \\
\hline 100 & 2 & 2 & 66 & 3 & 100 & 120 & 2 & 88 & 5 & 99 & 110 & 2 & 125 & 7 & 100 & 1 & 97 & Depth in Section in Centimeters \\
\hline-2 & & -2 & -1 & -1 & -1 & 0 & -1 & 0 & 0 & 0 & -1 & 0 & -1 & -1 & -1 & -1 & 0 & Reticulofenestra umbilica \\
\hline & -2 & -2 & -2 & -2 & -1 & 0 & -1 & 0 & 0 & 0 & -1 & 0 & -1 & -1 & -1 & -1 & -1 & Chiasmolithus gigas \\
\hline & & & -2 & & & -1 & -1 & 0 & 0 & 0 & -1 & 0 & & & -1 & -1 & -1 & Chiasmolithus grandis \\
\hline-2 & & -2 & 0 & 0 & 1 & 1 & 0 & 1 & 1 & 1 & 0 & 1 & -1 & 0 & 0 & 0 & 0 & Coccolithus pelagicus \\
\hline & & & -1 & -1 & -1 & -1 & -1 & 0 & 0 & 0 & -1 & 0 & -1 & -1 & -1 & -1 & -1 & Coccolithus eopelagicus \\
\hline-2 & & -1 & 0 & 0 & 0 & & 0 & 0 & 0 & -1 & -1 & -1 & -1 & & & & & Cyclococcolithus cf. floridanus \\
\hline & & & & -2 & & & -2 & -1 & & & & & & & -2 & -2 & -1 & Helicopontosphaera cf. seminulum \\
\hline & & & & $?$ & $?$ & & & -1 & & & & & & & & & & Helicopontosphaera parallela \\
\hline & & & & & & & & & & & & & & & & & -2 & Transversipontis pulcher \\
\hline & & & -2 & & -1 & 0 & -1 & 0 & 0 & 0 & -1 & 0 & -1 & -1 & & -1 & -1 & Epicoonia subdisticha \\
\hline & & & & & & & $?$ & & & & & & $?$ & & & & & Campylosphaera dela \\
\hline & & & & & & & & & & & & & & & -2 & & & Neococcolithes lososnensis \\
\hline & & & & & & & & & & & -2 & & -2 & & & & & Chiphragmalithus quadratus \\
\hline & & & -2 & & & & & & & & & & & & & & & Braarudosphaera undata \\
\hline & & & & & & & & & & & & & -2 & -2 & -2 & & & Micrantholithus basquensis \\
\hline & & & -2 & & & & & & & & & & & & & & -2 & Zygrhablithus bijugatus \\
\hline & & -2 & -2 & -1 & -1 & 0 & -1 & -1 & -1 & -1 & -2 & -1 & -2 & -2 & -1 & -1 & -1 & Discoaster barbadiensis \\
\hline & & & -2 & & & & -2 & & & & & & & -2 & & -2 & & Discoaster saipanensis \\
\hline & & & & & & -2 & -2 & -2 & -2 & -1 & & -1 & -2 & & & -2 & & Discoaster tani nodifer \\
\hline & & & & & -2 & & & & & & & & -2 & & & & & Discoaster gemmifer \\
\hline & & -2 & -2 & & & & & & & & & & & & & & -2 & Discoaster deflandrei \\
\hline
\end{tabular}


core catcher sample actually represents the sediment at the depth indicated.

The center bit brought up before taking Core 9 yielded a reddish clay containing a mixed assemblage with: Eiffellithus turriseiffeli, Micula staurophora, Watznaueria barnesae, Microrhabdulus decoratus, Lithraphidites carniolensis, Prediscosphaera cretacea, Zygodiscus lacunatus, Arkhangelskiella scapha and Discoaster sp. (Upper Cretaceous).

Only a core catcher sample was recovered by Core 9 , which is 1311 to 1326 feet (399 to 404 meters) beneath the sea floor, and this was barren of calcareous nannoplankton.

\section{Site 29 (lat. $14^{\circ} 47.11^{\prime} \mathrm{N}$, long. $69^{\circ} 19.36^{\prime} \mathrm{W}$ )}

This site was selected to provide an extensive fossiliferous section through the sediments of the Venezuelan Basin. The water depth at the site was 13,933 feet (4247 meters). Four holes were drilled.

Continuous coring was attempted in the first hole between the sediment surface and a depth of 180 feet (55 meters). Of the six 30-foot cores cut, only the first, second and fourth recovered sections of the sediment. Only small samples were available from the third, fifth and sixth cores. The distribution of calcareous nannofossils in the upper four cores-from 0 to 120 feet ( 0 to 37 meters) beneath the sea floor-is presented in Table 12. At the base of Core 4, the calcareous nannoflora becomes progressively more attacked by solution, and the bottom of Core 4 and samples from Cores 5 and 6 are devoid of calcareous nannofossils.

The upper part of Core 1 to the middle of Section 3 contains Gephyrocapsa oceanica and Pseudoemiliania lacunosa, and belongs to the lower part of the Upper Pleistocene G. oceanica Zone. The highest occurrence of Discoaster brouweri is in the middle of Section 2 of Core 2; the interval between this horizon and the first occurrence of G. oceanica in Section 3 of Core 1 can be assigned to the Gephyrocapsa Zone. Although fragments and a few isolated specimens of Discoaster pentaradiatus occur in higher samples, the last occurrence surface of $D$. pentaradiatus is probably within the interval which was to have been cored by Core 3 . Sphenolithus abies, which in other areas has its highest occurrence at a level intermediate between the highest occurrence of $D$. brouweri and the highest occurrence of $D$. surculus, does not occur in Pliocene samples from this site. All of the calcareous nannoplankton bearing sediments recovered by Core 4 belong to the $D$. surculus Zone. The lower boundary of the D. brouweri Zone and the S. abies Zone (if it were recognizable) must presumably lie in the interval which was to have been recovered by Core 3. Following Gartner (1969) the base of the $D$. surculus Zone is defined by the earliest occurrence of Pseudoemiliania lacunosa; the absence of this species from some samples in the lower part of Core 4 is probably due to selective solution. It is likely that Core 4 does not reach the base of the $D$. surculus Zone above the barren sediments.

A short sequence was obtained in Core 7 which is from 383 to 413 feet (117 to 126 meters) below the sea floor. Three samples from the single section of this core contained a few species of calcareous nannofossils: (70 centimeters) Reticulofenestra cf. umbilica, Cyclococcolithus floridanus, Discoaster deflandrei, $D$. extensus, D. dilatus, D. aulakos, D. cf. druggi, and Coccolithus eopelagicus; (190 centimeters) Reticulofenestra cf. umbilica, Coccolithus eopelagicus, and Discoaster nephados; (135 centimeters) Reticulofenestra cf. umbilica, Coccolithus eopelagicus, Discoaster dilatus, and $D$. nephados. In the subsequent hole, this lower Miocene assemblage was recovered at a higher level, and it is probable that the material sampled by Core 7 slumped from higher in the hole during the coring operation.

Continuous coring was attempted with 13 additional cores taken between 413 and 753 feet (126 and 229 meters) beneath the sea floor. These contain radiolarian ooze with sparse calcareous nannofossils present at some levels (see Table 13). The assemblages are limited frequently to a few species, and only Discoaster barbadiensis is common. Coccoliths show signs of solution, and specimens of Chiasmolithus are represented mostly by rims lacking the central cross. Discoaster saipanensis is present in Core 9, indicating a late Middle Eocene or Late Eocene age. Discoaster ornatus, a species probably restricted to the Discoaster sublodoensis Zone, is present in Cores 15 and 19, suggesting an early Middle Eocene or late Early Eocene Age for the lowest part of the sampled section.

A second hole drilled at this site, Hole 29A, attempted continuous coring with five cores taken between 133 and 283 feet ( 41 and 86 meters) beneath the sea floor. Recovery was poor in each case. Core 1 yielded a core catcher sample barren of calcareous nannofossils. A sample from the bottom of Core 2 contained a mixed Oligocene through Pleistocene assemblage with $\mathrm{Coc}$ colithus eopelagicus, Cyclococcolithus floridanus, $C$. leptoporus, Reticulofenestra umbilica, Gephyrocapsa aperta, Helicopontosphaera cf. seminulum, Discoaster brouweri, $D$. variabilis, $D$. extensus, $D$. dilatus, $D$. saundersi, Sphenolithus abies and S. ciperoensis. The origin of this sample, supposedly taken between 163 and 193 feet (49 and 59 meters) beneath the sea floor, is not clear; it seems to represent contamination from the previous hole. A sample from 67 centimeters in Section 1 of Core 2 was devoid of calcareous fossils. The core catcher sample from Core 3 contained a poor assemblage with Discoaster variabilis, D. pentaradiatus, 

TABLE 12

Distribution of Calcareous Nannofossils in Cores 1-4, Site 29

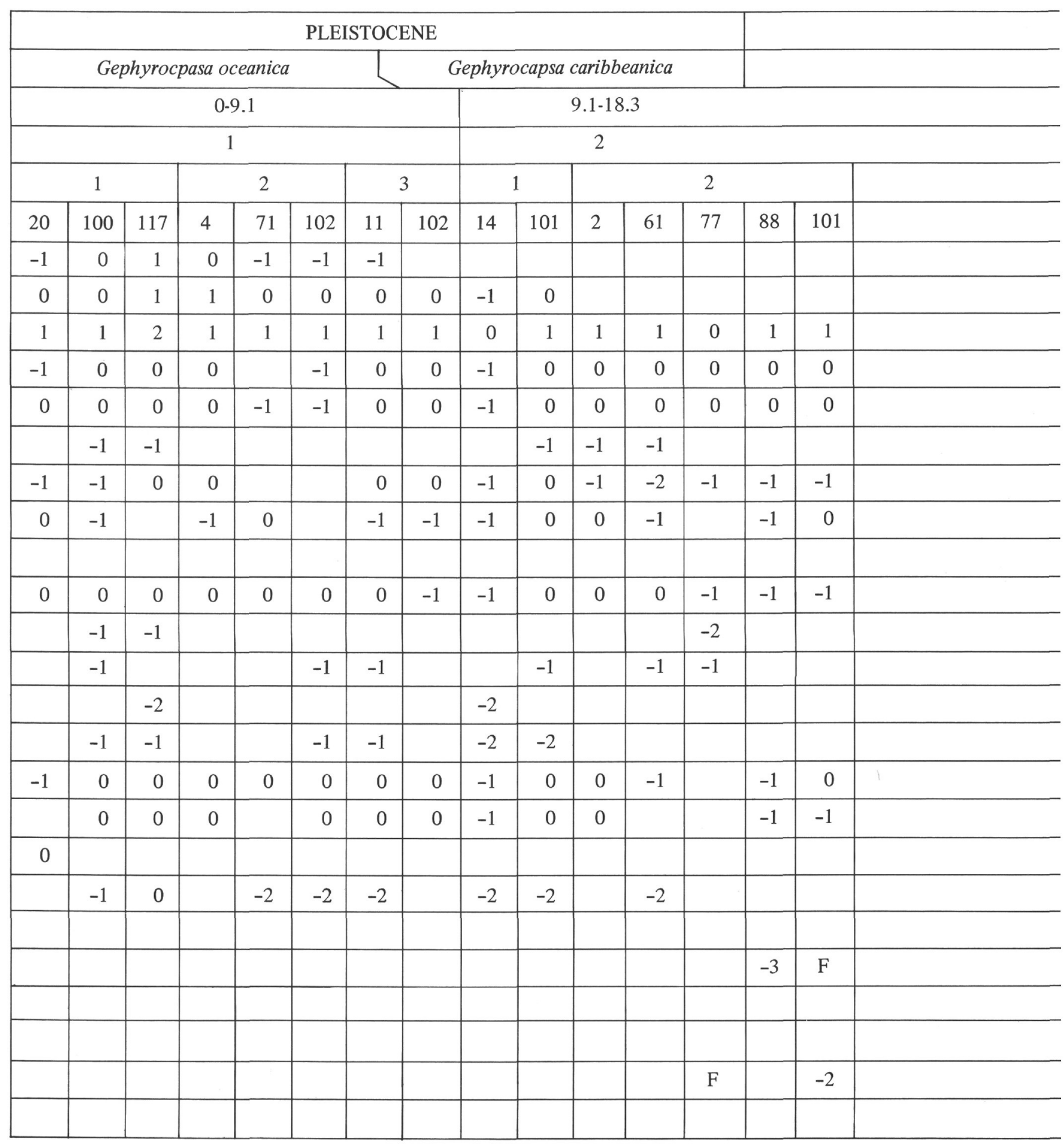




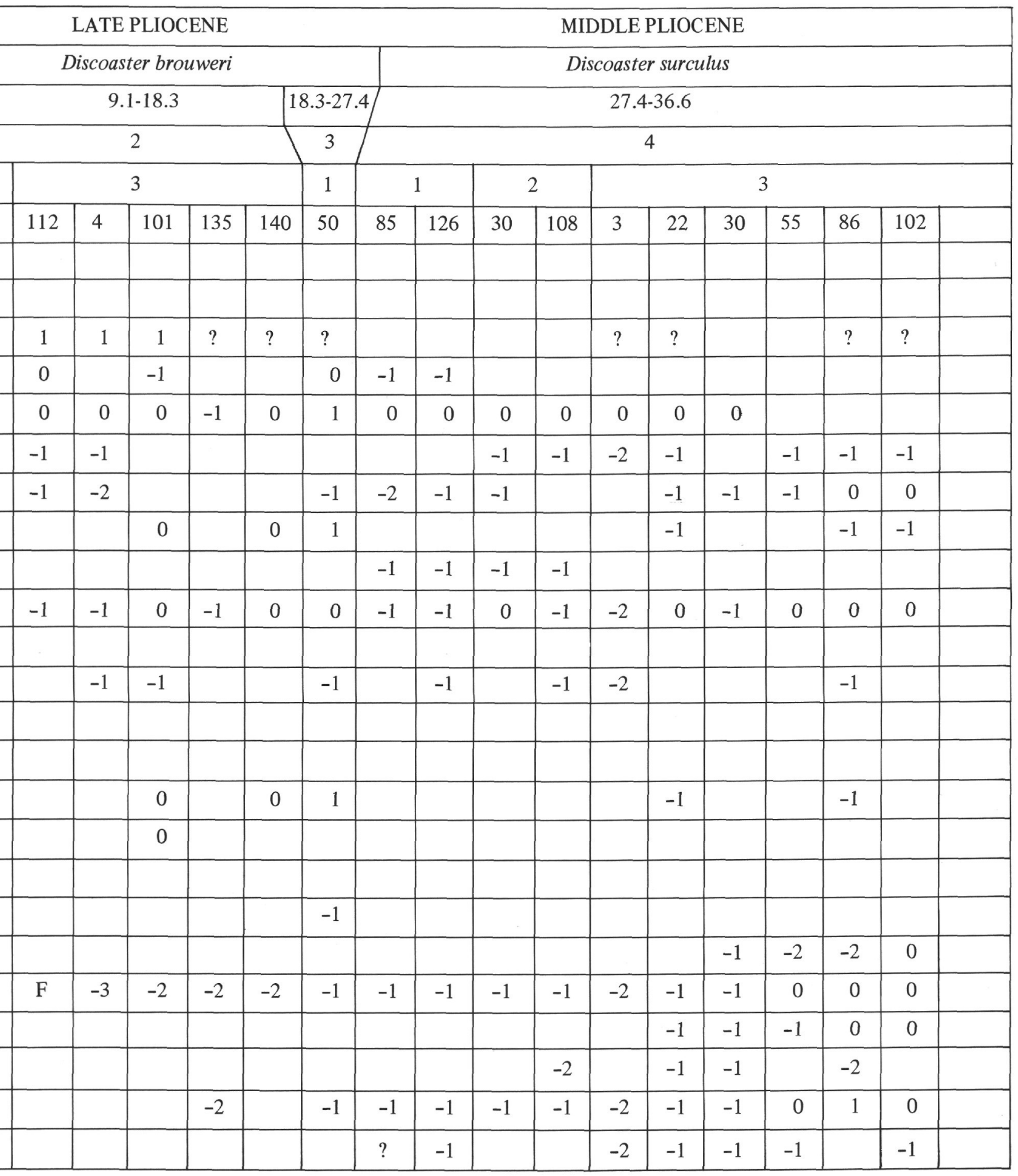


TABLE 12 - Continued

\begin{tabular}{|c|c|c|c|c|c|c|c|c|}
\hline \multicolumn{8}{|c|}{ MIDDLE PLIOCENE } & Age \\
\hline \multicolumn{8}{|c|}{ Discoaster surculus } & Zone \\
\hline \multicolumn{8}{|c|}{ 27.4-36.6 } & Depth Below Sea Floor in Meters \\
\hline \multicolumn{8}{|c|}{4} & Core Number \\
\hline \multicolumn{2}{|c|}{3} & \multicolumn{6}{|c|}{4} & Section Number \\
\hline 120 & 138 & 2 & 61 & 91 & 100 & 127 & 147 & Depth in Section in Centimeters \\
\hline & & & & & & & & Gephyrocapsa oceanica \\
\hline & & & & & & & & Gephyrocapsa aperta \\
\hline$?$ & & & $?$ & & $?$ & $?$ & & Gephyrocapsa caribbeanica \\
\hline & & & & & & & & Pseudoemiliania lacunosa (circular) \\
\hline & & & 0 & & & & & Pseudoemiliania lacunosa (elliptical) \\
\hline & -1 & 0 & 0 & 0 & 0 & -1 & $?$ & Coccolithus pelagicus \\
\hline & -1 & -1 & -1 & -1 & 0 & & & Cyclococcolithus leptoporus \\
\hline & & & & & & & & Umbilicosphaera mirabilis \\
\hline & & & -1 & & & & & Umbilicosphaera cricota \\
\hline 0 & 0 & & 0 & 0 & 0 & & $?$ & Helicopontosphaera kamptneri \\
\hline & & & & & & & & Helicopontosphaera wallichi \\
\hline & & & & & & & & Helicopontosphaera $\mathrm{cf}$ seminulum \\
\hline & & & & & & & & Pontosphaera scutellum \\
\hline & & & & & & & & Pontosphaera discopora \\
\hline & & & & & & & & “Discolithina" phaseola \\
\hline & & & & & & & & Aspidorhabdus stylifer \\
\hline & & & & & & & & Scapholithus fossilis \\
\hline & & & & & & & & Ceratolithus cristatus \\
\hline & & & -2 & -2 & & & & Ceratolithus rugosus \\
\hline-1 & -1 & 0 & -1 & 0 & 0 & -1 & & Discoaster brouweri rutellus \\
\hline 0 & 0 & 0 & -1 & -1 & -1 & & & Discoaster brouweri tridenus \\
\hline & & & -2 & -2 & & & & Discoaster brouweri tamalis \\
\hline 0 & 0 & 0 & 0 & -1 & & & & Discoaster pentaradiatus \\
\hline-1 & & & -1 & -1 & -1 & & & Discoaster surculus \\
\hline
\end{tabular}


TABLE 13

Distribution of Calcareous Nannofossils in Cores 9, 12, 15 and 19, Site 29

\begin{tabular}{|c|c|c|c|c|c|c|c|c|c|c|c|c|c|}
\hline \multicolumn{13}{|c|}{ MIDDLE EOCENE } & \multirow{2}{*}{$\begin{array}{l}\text { Age } \\
\text { Zone }\end{array}$} \\
\hline$?$ & $?$ & $?$ & $?$ & $?$ & 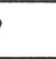 & & & $?$ & $?$ & $?$ & $?$ & $?$ & \\
\hline \multicolumn{4}{|c|}{$135.0-144.2$} & \multicolumn{3}{|c|}{$162.5-171.6$} & \multicolumn{4}{|c|}{$192.9-202.1$} & \multicolumn{2}{|c|}{$224.9-226.5$} & Depth Below Sea Floor in Meters \\
\hline \multicolumn{4}{|c|}{9} & \multicolumn{3}{|c|}{12} & \multicolumn{4}{|c|}{15} & \multicolumn{2}{|c|}{19} & Core Number \\
\hline 2 & \multicolumn{3}{|c|}{3} & 3 & 4 & 6 & 1 & 2 & 4 & 6 & 2 & 3 & Section Number \\
\hline \multirow[t]{3}{*}{94} & 5 & 67 & 74 & 36 & 20 & 43 & 7 & 8 & 7 & 4 & 10 & 18 & Depth in Section in Centimeters \\
\hline & & & -1 & & & & & & & & & & Reticulofenestra umbilica \\
\hline & & & & & 0 & -1 & -1 & & 0 & & & & Coccolithus pelagicus \\
\hline \multirow[t]{4}{*}{-1} & & -1 & $\overline{-1}$ & & 0 & -1 & & & & -1 & & -1 & Coccolithus eopelagicus \\
\hline & & -1 & & & 0 & & & & & & & & Chiasmolithus sp. (rim only) \\
\hline & & & & & 0 & & & & & & & & Chiasmolithus grandis \\
\hline & & & & - & & & & & & & & & Sphenolithus moriformis \\
\hline \multirow[t]{4}{*}{0} & -1 & 0 & 0 & & 0 & -1 & 0 & 0 & -1 & 0 & 0 & 0 & Discoaster barbadiensis \\
\hline & & -1 & -1 & $?$ & $?$ & & & & & & & & Discoaster saipanensis \\
\hline & & & & & & -1 & -1 & -1 & -1 & -2 & -1 & -1 & Discoaster ornatus \\
\hline & & & & - & & & & & & & & & Discoaster tani tani \\
\hline
\end{tabular}


TABLE 14

Distribution of Calcareous Nannofossils in Cores 2-5, Site 29B

\begin{tabular}{|c|c|c|c|c|c|c|c|c|c|c|}
\hline \multicolumn{5}{|c|}{ LATE MIOCENE } & \multicolumn{6}{|c|}{ EARLY MIOCENE } \\
\hline \multicolumn{5}{|c|}{ Discoaster hamatus } & \multicolumn{6}{|c|}{ Helicopontosphaera ampliaperta } \\
\hline \multicolumn{3}{|c|}{$67.1-76.8$} & \multicolumn{2}{|c|}{$78.3-87.5$} & \multicolumn{3}{|c|}{$87.5-96.6$} & \multicolumn{3}{|c|}{$96.6-105.8$} \\
\hline \multicolumn{4}{|c|}{2} & 3 & \multicolumn{3}{|c|}{4} & \multicolumn{3}{|c|}{5} \\
\hline \multicolumn{2}{|c|}{3} & \multicolumn{2}{|c|}{4} & 1 & \multicolumn{3}{|c|}{4} & 1 & \multicolumn{2}{|c|}{2} \\
\hline 13 & 95 & 90 & 107 & 5 & 63 & 100 & 137 & 100 & 19 & 100 \\
\hline 0 & 0 & 0 & 0 & -1 & 0 & 0 & 0 & 0 & 0 & 0 \\
\hline & & & & & -1 & -1 & -1 & -1 & -1 & -1 \\
\hline-1 & -1 & & -1 & -1 & -1 & -1 & -1 & -1 & -1 & -1 \\
\hline & & & & & & -1 & -1 & -1 & -1 & 0 \\
\hline 0 & 0 & 0 & 0 & & 0 & 0 & 0 & 0 & & \\
\hline 0 & 0 & -1 & 0 & & & & & & & \\
\hline & & & & & -1 & -1 & -1 & -1 & -1 & -1 \\
\hline & 0 & 0 & 0 & & -1 & -1 & -1 & -1 & -1 & \\
\hline 1 & 1 & 1 & 1 & 1 & 0 & 0 & 0 & & & \\
\hline 0 & 0 & 0 & & & & & & & & \\
\hline & -2 & & & -2 & & & & & & \\
\hline-1 & -1 & & & & & & & & & \\
\hline 0 & 0 & 0 & 0 & 0 & & & & & & \\
\hline 0 & 0 & -1 & 0 & 0 & 0 & 0 & 0 & & & \\
\hline 1 & & 1 & -1 & & 0 & 0 & 0 & & & \\
\hline & & & & & -1 & -1 & & & & \\
\hline & & & & & & & & & -2 & \\
\hline & & & & & & & & & -2 & \\
\hline & & & & & & -2 & & & & \\
\hline & $?$ & -1 & -2 & -2 & & & & & & \\
\hline & & & & & -1 & & -1 & 0 & 0 & 0 \\
\hline & & & & & & & & & -1 & 0 \\
\hline & & & & & & & & -1 & 0 & -1 \\
\hline & & & & & 0 & 0 & 1 & 0 & 0 & 0 \\
\hline-1 & & & & & & & & & & \\
\hline
\end{tabular}




\begin{tabular}{|c|c|c|c|c|c|c|}
\hline \multicolumn{6}{|c|}{ EARLY MIOCENE } & Age \\
\hline \multicolumn{6}{|c|}{ Helicopontosphaera ampliaperta } & Zone \\
\hline \multicolumn{6}{|c|}{$96.6-105.8$} & Depth Below Sea Floor in Meters \\
\hline \multicolumn{6}{|c|}{5} & Core Number \\
\hline \multicolumn{3}{|c|}{3} & \multicolumn{3}{|c|}{4} & Section Number \\
\hline 17 & 50 & 118 & 10 & 60 & 115 & Depth in Section in Centimeters \\
\hline 0 & 0 & 0 & 0 & 0 & 0 & Coccolithus pelagicus \\
\hline \multirow[t]{2}{*}{-1} & -1 & -1 & -1 & -1 & -1 & Coccolithus eopelagicus \\
\hline & & & & & & Reticulofenestra pseudoumbilica \\
\hline \multirow[t]{4}{*}{0} & 0 & 0 & 0 & 0 & 0 & Reticulofenestra laevis \\
\hline & & & & & & Cyclococcolithus leptoporus \\
\hline & & & & & & Umbilicosphaera cricota \\
\hline & & 0 & -1 & 0 & -1 & Coronocyclus nitescens \\
\hline \multirow[t]{14}{*}{-1} & -1 & 0 & -1 & -1 & -1 & Helicopontosphaera ampliaperta \\
\hline & & & & & & Helicopontosphaera kamptneri \\
\hline & & & & & & Discoaster brouweri rutellus \\
\hline & & & & & & Discoaster brouweri tridenus \\
\hline & & & & & & Discoaster brouweri triradiatus \\
\hline & & & & & & Discoaster pentaradiatus \\
\hline & & & & & & Discoaster quinqueramus \\
\hline & & & & & & Discoaster extensus \\
\hline & & & 0 & -1 & -1 & Discoaster variabilis \\
\hline & & & & & & Discoaster exilis \\
\hline & & & & & & Discoaster perplexus \\
\hline & & & & & & Discoaster obtusus \\
\hline & & & & & & Discoaster bollii \\
\hline & & & & & & Discoaster hamatus (six rayed) \\
\hline 0 & 0 & 0 & 0 & 0 & -1 & Discoaster aulakos \\
\hline 0 & 0 & 0 & 0 & 0 & 0 & Discoaster deflandrei \\
\hline \multirow[t]{2}{*}{-1} & -1 & & & & & Discoaster trinidadensis \\
\hline & & -1 & & & & Discoaster saundersi \\
\hline \multirow[t]{2}{*}{0} & 0 & 0 & 0 & 0 & 0 & Sphenolithus heteromorphus \\
\hline & & & & & & Triquetrorhabdulus rugosus \\
\hline
\end{tabular}


D. perclarus and five-rayed specimens of Discoaster hamatus. The section of sediment recovered in Core 4 contained calcareous nannofossils only at 27 centimeters, where Discoaster brouweri, D. pentaradiatus, $D$. bollii, and six-rayed specimens of D. hamatus were present. Although these assemblages are of late Middle Miocene or early Late Miocene age, the occurrence of five-rayed specimens of $D$. hamatus above six-rayed specimens of that species suggests that the two fossiliferous samples are not in the correct stratigraphic order. At this point, Hole 29A was abandoned on the assumption that the drilling tools had re-entered the hole drilled earlier.

A third hole, Hole 29B, was drilled at the same site in order to recover that part of the sedimentary column not successfully sampled in the two previously drilled holes. Continuous coring was attempted, with eight cores being taken between 187 and 437 feet (57 and 133 meters) beneath the sea floor. Sediments of the first core-187 to 217 feet ( 57 to 66 meters) below the sea floor-are devoid of calcareous nannoplankton fossils. Cores 2 through 5 -from 222 to 347 feet (68 to 106 meters) beneath the sea floor-had spotty distribution of calcareous nannoplankton, with specimens abundant at some levels but absent at others. Sediments recovered in Cores 2 -from 222 to 252 feet (68 to 77 meters) below the sea floor-and 3, a poor recovery of a single short section from 257 to 287 feet (78 to 87 meters) beneath the sea floor, contain six-rayed specimens of Discoaster hamatus, indicating that they are assignable to the upper part of the Discoaster hamatus Zone (lower Upper Miocene). Core 4 from 287 to 317 feet (87 to 97 meters) beneath the sea floor and Core 5 from 317 to 347 feet (97 to 106 meters) beneath the sea floor contain both Helicopontosphaera ampliaperta and Sphenolithus heteromorphus, and belong to the upper Lower Miocene Helicopontosphaera ampliaperta Zone. A sample from 95 centimeters in Section 1 of Core 6, from 347 to 377 feet (106 to 115 meters) below the sea floor, contains Reticulofenestra cf. laevis, Sphenolithus heteromorphus, Discoaster deflandrei, D. nephados, D. trinidadensis, and $D$. aulakos, and probably belongs to the lower part of the Helicopontosphaera ampliaperta Zone. Samples from Core 7 from 377 to 407 feet (115 to 124 meters) below the sea floor are devoid of calcareous nannofossils. Core 8 from 407 to 437 feet (124 to 133 meters) below the sea floor recovered radiolarian ooze without calcareous fossils.

Two cores were taken at a greater depth in Hole 29B between 716 and 760 feet ( 218 and 232 meters) below the sea floor; these recovered radiolarian ooze lacking calcareous fossils.

A fourth hole, Hole 29C, was drilled at the same site in an attempt to recover deeper sediments. Three cores were cut between 753 and 813 feet (229 and 248 meters) beneath the sea floor, recovering small sections of chert and some radiolarian ooze lacking calcareous nannofossils.

\section{Site 30 (lat. $12^{\circ} 52.92^{\prime} \mathrm{N}$, long. $63^{\circ} 23.00^{\prime} \mathrm{W}$ )}

This site, on the Aves Ridge in water 3994 feet (1218 meters) deep, was drilled in order to recover a Neogene section with calcareous fossils. Sixteen cores were cut; all of the sediment reeovered contains calcareous nannoplankton. The preservation of the nannofossils is excellent at the top of the section, but becomes progressively poorer with depth. Because these deposits were almost certainly laid down above the zone of calcium carbonate compensation, it is suggested that corrosion of the calcareous nannofossils occurred after burial.

Distribution of the calcareous nannofossils in Cores 1 through 8 is shown in Table 15; distribution of calcareous nannofossils in Cores 9 through 16 is shown in Table 16.

Cores 1 and 2 contain Gephyrocapsa oceanica and dominantly circular forms of Pseudoemiliania lacunosa, indicating the upper part of the lower part of the $G$. oceanica Zone. Core 3 and the upper part of Core 4, from 353 to 390 feet (108 to 119 meters) below the sea floor, contain $G$. oceanica and predominantly oval forms of $P$. lacunosa, indicating the lower part of the lower part of the G. oceanica Zone. The lowest occurrence of $G$. oceanica is within Section 2 of Core 4.

The lower part of Core 4, all of Core 5, and the upper part of Core 6-from about 390 to 575 feet (119 to 175 meters) beneath the sea floor-are referable to the Lower Pleistocene Gephyrocapsa caribbeanica Zone, as these sediments lie below the lowest occurrence of $G$. oceanica and above the probable highest occurrence of Discoaster brouweri.

The lower part of Core 6 , and all of the sediments recovered in Cores 7 and 8, from about 575 to 1073 feet (175 to 327 meters) beneath the sea floor, belong to the Discoaster brouweri Zone and are of Late Pliocene age. The highest occurrence of Discoaster pentaradiatus is below the highest occurrence of $D$. brouweri, as has been noted at other localities.

Cores 9 and 10 contain Discoaster quinqueramus, and probably represent strata above the highest occurrence of Discoaster hamatus (Upper Miocene).

The strata in Cores 11 and 12 contain Discoaster kugleri at several levels although it is apparently rare or absent at other levels. The interval represented by these cores can be referred tentatively to the $D$. kugleri Zone. 
TABLE 15

Distribution of Calcareous Nannofossils in Cores 1-8, Site 30

\begin{tabular}{|c|c|c|c|c|c|c|c|c|c|c|c|c|c|c|c|}
\hline \multicolumn{16}{|c|}{ PLEISTOCENE } \\
\hline \multicolumn{16}{|c|}{ Gephyrocapsa oceanica } \\
\hline \multicolumn{5}{|c|}{$50.3-59.4$} & \multicolumn{4}{|c|}{$59.4-68.6$} & \multicolumn{7}{|c|}{$107.6-116.7$} \\
\hline \multicolumn{5}{|c|}{1} & \multicolumn{4}{|c|}{2} & \multicolumn{7}{|c|}{3} \\
\hline 1 & 2 & 3 & \multicolumn{2}{|c|}{5} & 2 & 3 & \multicolumn{2}{|c|}{4} & 1 & \multicolumn{2}{|c|}{2} & \multicolumn{2}{|c|}{3} & \multicolumn{2}{|c|}{4} \\
\hline 78 & 100 & 106 & 1 & 100 & 8 & 101 & 4 & 102 & 120 & 6 & 101 & 13 & 102 & 11 & 100 \\
\hline 1 & 1 & 0 & 1 & 0 & 0 & & 0 & 0 & 0 & 0 & -1 & -1 & -1 & -1 & -1 \\
\hline-1 & -1 & 0 & -1 & 0 & -1 & & -1 & -1 & -1 & -1 & -1 & -1 & 0 & 0 & -1 \\
\hline 1 & 1 & 0 & 1 & 0 & 0 & -1 & 0 & 0 & 0 & 0 & 0 & 0 & 0 & 0 & 0 \\
\hline-1 & 0 & -1 & C & -1 & -1 & -2 & -1 & -1 & & & & & & & \\
\hline & & & & & & & -1 & -1 & -1 & -1 & -1 & -1 & -2 & -1 & -1 \\
\hline & & & & -1 & & & -1 & & -1 & & & & -2 & & \\
\hline & -1 & & & & & & -2 & & & & & -1 & & & \\
\hline 0 & 0 & -1 & c & -1 & & & -1 & -1 & -1 & -1 & -1 & & -2 & -2 & -1 \\
\hline-2 & -2 & & -2 & & & & & & & & & & & & \\
\hline & & & & & & & & & & & -2 & & & & \\
\hline & -1 & & & & & & & & & & & & & & -2 \\
\hline 0 & 0 & 0 & c & 0 & & & & 0 & 0 & 0 & & & -1 & -1 & 0 \\
\hline 0 & 0 & & c & & & & & 0 & 0 & 0 & & -1 & & -1 & 0 \\
\hline & & & -2 & & -2 & & & -1 & & & & & & & \\
\hline & & & & & & & & & & & & & & & \\
\hline & & & & & & & & & & & & & & & \\
\hline & & & & & & & & & & & & & & & \\
\hline & & & & & & & & & & & & & & & \\
\hline
\end{tabular}


TABLE 15 - Continued

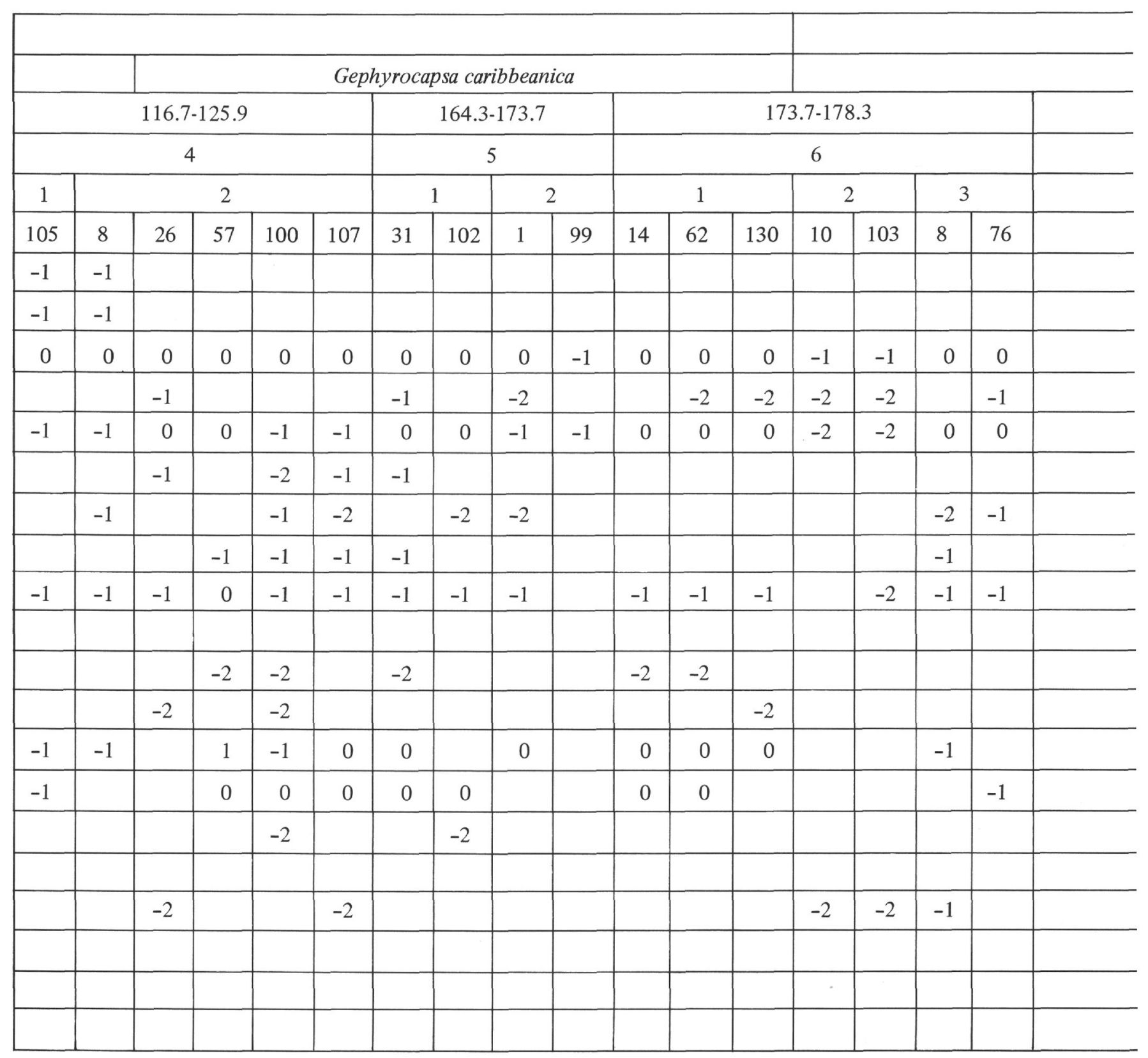




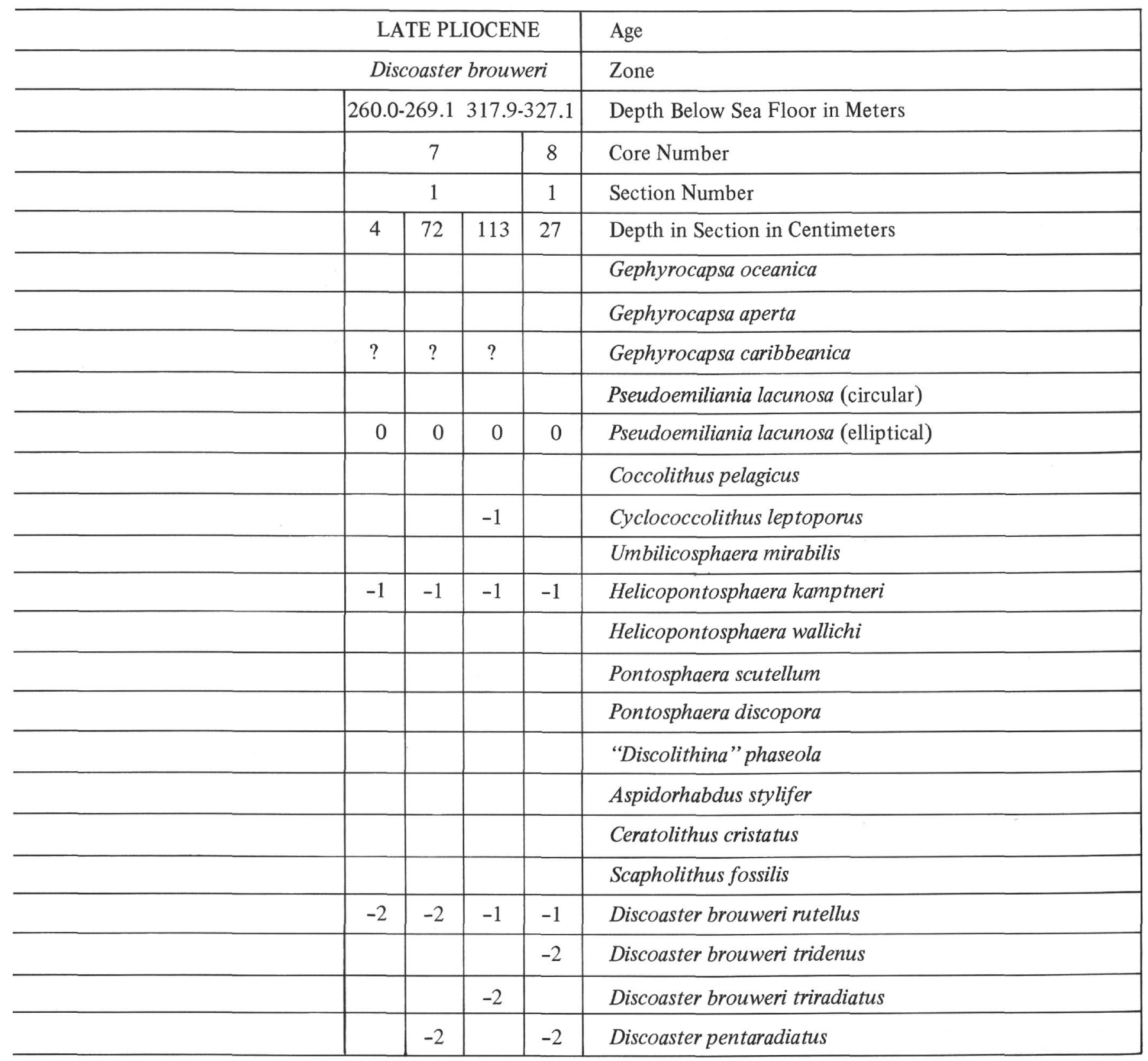


TABLE 16

Distribution of Calcareous Nannofossils in Cores 9 -16, Site 30

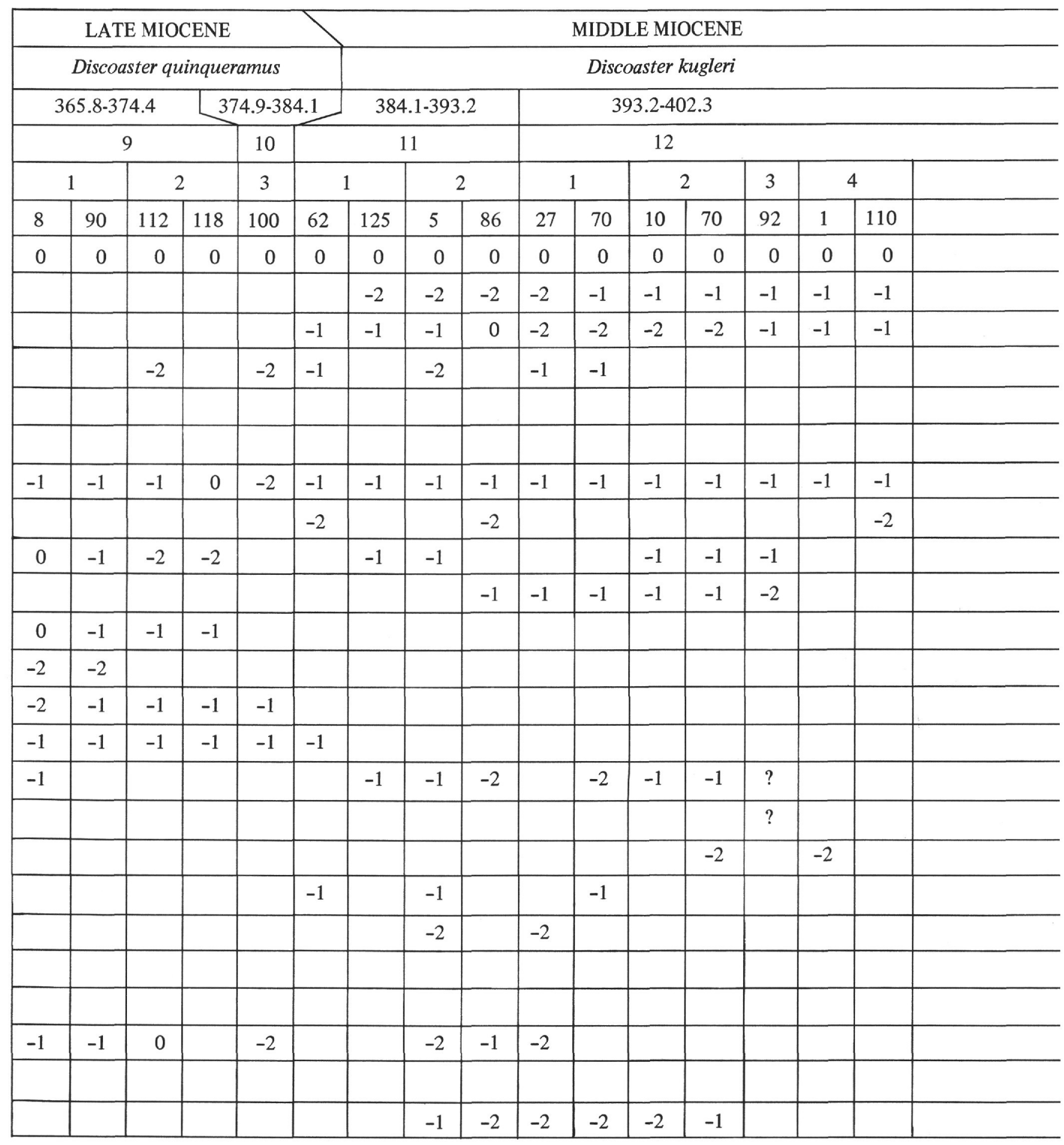




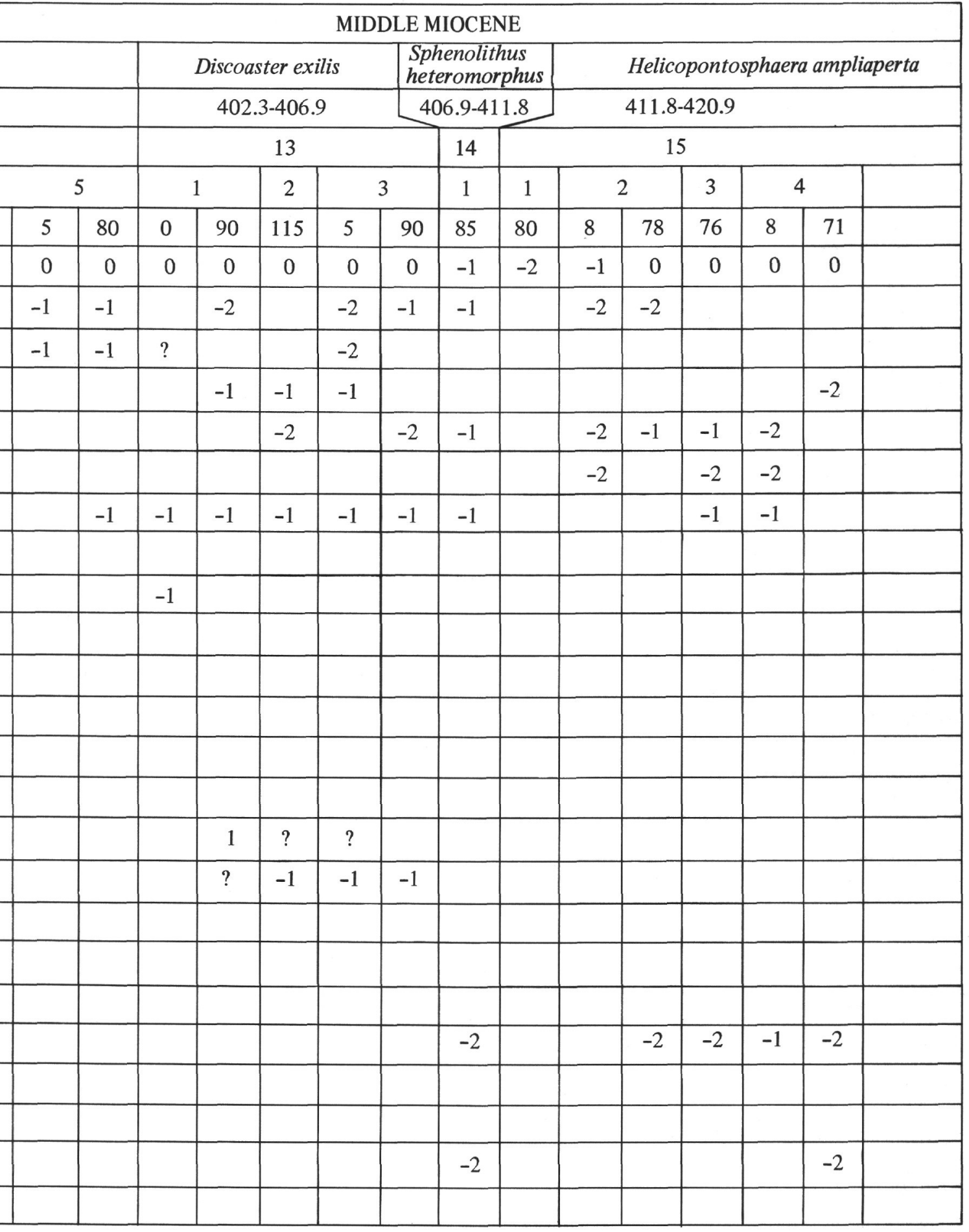


TABLE 16 - Continued

\begin{tabular}{|c|c|c|c|}
\hline \multicolumn{3}{|c|}{ EARLY MIOCENE } & Age \\
\hline \multicolumn{3}{|c|}{ Helicopontosphaera ampliaperta } & Zone \\
\hline \multicolumn{3}{|c|}{$420.9-430.1$} & Depth Below Sea Floor in Meters \\
\hline & & 16 & Core Number \\
\hline & 5 & 1 & Section Number \\
\hline 0 & 98 & 53 & Depth in Section in Centimeters \\
\hline 0 & 0 & -1 & Coccolithus pelagicus \\
\hline-2 & & & Coccolithus eopelagicus \\
\hline & & & Reticulofenestra pseudoumbilica \\
\hline & -2 & & Cyclococcolithus leptoporus \\
\hline-1 & & -2 & Cyclococcolithus floridanus \\
\hline-2 & -1 & -2 & Helicopontosphaera ampliaperta \\
\hline-1 & -1 & -2 & Helicopontosphaera intermedia \\
\hline & & & Discoaster brouweri brouweri \\
\hline & & & Discoaster brouweri rutellus \\
\hline & & & Discoaster brouweri calcaris \\
\hline & & & Discoaster brouweri tridenus \\
\hline & & & Discoaster pentaradiatus \\
\hline & & & Discoaster quinqueramus \\
\hline & & & Discoaster extensus \\
\hline & & & Discoaster variabilis \\
\hline & & & Discoaster exilis \\
\hline & & & Discoaster bollii \\
\hline & & & Discoaster kugleri \\
\hline & -1 & & Discoaster deflandrei \\
\hline-2 & -2 & -2 & Discoaster aulakos \\
\hline-2 & & & Discoaster trinidadensis \\
\hline & & & Sphenolithus abies \\
\hline & & -2 & Sphenolithus heteromorphus \\
\hline & & & Triquetrorhabdulus rugosus \\
\hline
\end{tabular}


Core 13 recovered sediments with an abundance of Discoaster exilis, but lacking D. kugleri and Sphenolithus heteromorphus; it is assigned here to the D. exilis Zone.

Core 14 recovered a short section with Sphenolithus heteromorphus, but lacking Helicopontosphaera ampliaperta, assignable to the Sphenolithus Heteromorphus Zone.

Core 15 from 1351 to 1381 feet (412 to 421 meters) beneath the sea floor recovered a substantial section with Helicopontosphaera ampliaperta and Sphenolithus heteromorphus, referable to the $H$. ampliaperta Zone. Core 16 recovered only a short section with essentially the same calcareous nannoplankton assemblage, indicating that the strata at the base of the hole also belong to the $H$. ampliaperta Zone. Planktonic foraminifera from Core 16 belong the to Praeorbulina glomerosa Zone, assigned to the Lower Miocene, so that the $H$. ampliaperta Zone must span the Lower-Middle Miocene boundary as used in these reports.

\section{Site 31 (lat. $14^{\circ} 56.60^{\prime} \mathrm{N}$, long. $72^{\circ} 1.63^{\prime} \mathrm{W}$ )}

This hole was drilled in a water depth of 11,049 feet (3369 meters) on the Beata Ridge to recover Tertiary sediments. Ten cores were cut. Distribution of calcareous nannoplankton fossils in these cores is indicated in Tables 17 (Cores 1 and 2), 18 (Cores 3 through 7), and 19 (Cores 8,9 and 10).

Core 1 contains Gephyrocapsa oceanica but lacks Pseudoemiliania lacunosa, indicating that it represents the upper part of the Late Pleistocene Gephyrocapsa oceanica Zone.

Core 2 recovered only a short section of sediment containing Gephyrocapsa aperta and $G$. caribbeanica, along with Pseudoemiliania lacunosa; the sample examined is from the upper part of the Early Pleistocene Gephyrocapsa caribbeanica Zone.

Core 3 contains Discoaster brouweri throughout, but lacks $D$. pentaradiatus, indicating that the entire core belongs to the upper part of the $D$. brouweri Zone (Late Pliocene in age).

The uppermost sample from Core 4 may belong to the base of the $D$. brouweri Zone, but the lower parts of this core are below the highest occurrence of Sphenolithus abies, and belong to the Upper Pliocene $S$. abies Zone.

The sediments of Cores 5, 6 and 7 contain Discoaster brouweri and $D$. pentaradiatus, but not $D$. surculus. Because these strata lie below the highest occurrence of Sphenolithus abies, and apparently above the highest occurrence of $D$. surculus, they are also referred to the $S$. abies Zone.
Core 8 contains a calcareous nannoplankton assemblage typical for the Discoaster exilis Zone.

The calcareous nannoplankton assemblage in Core? from 696 to 726 feet (212 to 221 meters) beneath the sea floor can be assigned to the Lower Miocene, but does not contain species diagnostic of the zones in current use.

Core 10 from 886 to 916 feet (270 to 279 meters) beneath the sea floor contains an interesting assemblage with Triquetrorhabdulus carinatus and with Discoaster lidzi in the lower sections; the assignment of this assemblage to the Sphenolithus ciperoensis Zone is appropriate because of the presence of $D$. lidzi.

\section{REFERENCES}

Boudreaux, J. E. and Hay, W. W., 1969. Calcareous nannoplankton and biostratigraphy of the Late Pliocene-Pleistocene-Recent sediments in the Submarex cores. Rev. Micropaleontol. 1,249.

Bramlette, M. N. and Sullivan, R. F., 1961. Coccolithophorids and related nannoplankton of the early Tertiary in California. Micropaleontology. 7, 129.

Bramlette, M. N. and Wilcoxon, J. A., 1967. Middle Tertiary calcareous nannoplankton of the Cipero section, Trinidad, W.I. Tulane Studies Geol. 5, 93.

Gartner, S., Jr., 1967. Calcareous nannofossils from Neogene of Trinidad, Jamaica, and Gulf of Mexico. Univ. Kansas Publ. State Geol. Surv. Paleont. Contr. 29,1 .

1968. Coccoliths and related calcareous nannofossils from Upper Cretaceous deposits of Texas and Arkansas. Univ. Kansas Publ. State Geol. Surv. Paleont. Contr. Protista Art. 1, 1.

1968. Correlation of Neogene planktonic foraminifer and calcareous nannofossil zones. Trans. Gulf Coast Assoc. Geol. Soc. 19, 585.

Hay, W. W., Mohler, H. P., Roth, P. H., Schmidt, R. R. and Boudreaux, J. E., 1967. Calcareous nannoplankton zonation of the Cenozoic of the Gulf Coast and Caribbean-Antillean area and transoceanic correlation. Trans. Gulf Coast Assoc. Geol. Soc. 17,428 .

Hay, W. W., Mohler, H. P. and Wade, M. E., 1966. Calcareous nannofossils from Nal'chik (Northwest Caucasus). Eclogae Geol. Helv. 59, 379.

Kamptner, E., 1967. Kalkflagellaten-Skelettreste aus Tiefseeschlamm des Südatlantischen Ozeans. Ann. Naturhist. Museums. Wien, 71, 117.

Loeblich, A. R., Jr. and Tappan, H., 1966. Annotated index and bibliography of the calcareous nannoplankton. Phycologia. 5, 81 .

, 1968. Annotated index and bibliography of the calcareous nannoplankton II. J. Paleontol. 42, 584. 
TABLE 17

Distribution of Calcareous Nannofossils in Cores 1-2, Site 31

\begin{tabular}{|c|c|c|c|c|c|c|c|c|c|c|c|c|c|c|c|c|c|c|}
\hline \multicolumn{18}{|c|}{ PLEISTOCENE } & Age \\
\hline \multicolumn{15}{|c|}{ Gephyrocapsa oceanica } & \multicolumn{3}{|c|}{$\begin{array}{l}\text { Gephyrocapsa } \\
\text { caribbeanica }\end{array}$} & Zone \\
\hline & & & \multicolumn{12}{|c|}{$0-9.1$} & \multicolumn{3}{|c|}{$32.0-41.2$} & Depth Below Sea Floor in Meters \\
\hline & & & \multicolumn{12}{|c|}{1} & \multicolumn{3}{|c|}{2} & Barrel Core \\
\hline \multicolumn{4}{|c|}{1} & \multicolumn{2}{|c|}{2} & \multicolumn{4}{|c|}{3} & \multicolumn{2}{|c|}{4} & \multicolumn{3}{|c|}{5} & \multicolumn{2}{|c|}{6} & 1 & Section Number \\
\hline 3 & 50 & 100 & 2 & 50 & 100 & 2 & 50 & 100 & 2 & 50 & 100 & 2 & 48 & 120 & 18 & 125 & 0 & Depth in Section in Centimeters \\
\hline 1 & 1 & 1 & 1 & 1 & 0 & 0 & 0 & 0 & 0 & 0 & 0 & 0 & 0 & 0 & 0 & 0 & 0 & Gephyrocapsa oceanica \\
\hline 0 & 0 & 0 & 0 & 0 & 0 & 1 & 1 & 1 & 1 & 1 & 1 & 1 & 0 & 0 & 0 & 0 & 0 & Gephyrocapsa aperta \\
\hline & & & -1 & -1 & 0 & 0 & 1 & 1 & 1 & 1 & 1 & 1 & 1 & 1 & 1 & 1 & 0 & Gephyrocapsa caribbeanica \\
\hline & & & & & & & & & & & & & & -2 & & & -1 & Pseudoemiliania lacunosa (circular) \\
\hline & & & & & & & & & & & & & & & & & -1 & Pseudoemiliania lacunosa (elliptical) \\
\hline & & -2 & & & & & & & & & & & & & & & & Coccolithus pelagicus \\
\hline & & & & -2 & & & & & & -2 & -1 & -1 & -1 & & & & & Cyclococcolithus leptoporus \\
\hline-1 & -1 & -1 & -1 & -1 & -2 & & & & & & & & & -2 & & & & Umbilicosphaera mirabilis \\
\hline-1 & -1 & -1 & -1 & 0 & -1 & -1 & -1 & -1 & -1 & -1 & -1 & -1 & -1 & -1 & -1 & -1 & -1 & Helicopontosphaera kamptneri \\
\hline & & & & & & -2 & & & & & & -2 & & & & & & Helicopontosphaera wallichi \\
\hline & & & & & & & & & -2 & & & & & & & & & Helicopontosphaera cf. seminulum \\
\hline-2 & & & -2 & & & & & & & - & & -2 & & & & & & Pontosphaera scutellum \\
\hline-2 & & & & & & & & & & & & & & & & & -2 & Pontosphaera discopora \\
\hline 0 & 0 & 0 & 0 & 0 & 0 & 0 & -1 & -1 & -1 & -1 & 0 & 0 & 0 & -1 & 0 & 0 & -1 & "Discolithina" phaseola \\
\hline 1 & 0 & 0 & 0 & -1 & -1 & 0 & -2 & -1 & -1 & -1 & 0 & 0 & 0 & & -1 & -1 & -1 & Aspidorhabdus stylifer \\
\hline & & & & & & & & & & & & & & & & & & Rhabdosphaera clavigera \\
\hline-2 & & & & & -2 & & & & -2 & & & & & & & & & Ceratolithus cristatus \\
\hline 1 & -1 & 0 & & & -1 & & & -1 & & -1 & 0 & 0 & 0 & & & & & Scapholithus fossilis \\
\hline
\end{tabular}


TABLE 18

Distribution of Calcareous Nannofossils in Cores 3-7, Site 31

\begin{tabular}{|c|c|c|c|c|c|c|c|c|c|c|c|c|c|c|c|c|}
\hline \multicolumn{17}{|c|}{ LATE PLIOCENE } \\
\hline \multicolumn{17}{|c|}{ Discoaster brouweri } \\
\hline \multicolumn{14}{|c|}{$60.4-69.5$} & \multicolumn{3}{|c|}{$69.5-78.6$} \\
\hline \multicolumn{14}{|c|}{3} & \multicolumn{3}{|c|}{4} \\
\hline \multicolumn{2}{|c|}{1} & \multicolumn{3}{|c|}{2} & \multicolumn{3}{|c|}{3} & \multicolumn{3}{|c|}{5} & \multicolumn{3}{|c|}{6} & \multicolumn{3}{|c|}{1} \\
\hline 2 & 50 & 2 & 50 & 100 & 2 & 50 & 105 & 1 & 50 & 100 & 2 & 50 & 100 & 4 & 50 & 100 \\
\hline$?$ & $?$ & $?$ & $?$ & $?$ & $?$ & $?$ & & & & & & & & & & \\
\hline & & & & & & & & -1 & -1 & -1 & -1 & -1 & -1 & -1 & -1 & -1 \\
\hline 1 & 0 & 0 & 1 & 1 & 0 & 0 & 0 & 0 & 0 & 0 & -1 & 0 & 0 & 0 & 0 & 0 \\
\hline 0 & -1 & -1 & -1 & 0 & 0 & -1 & -1 & & -1 & -1 & & & & -2 & -2 & -2 \\
\hline & -1 & & & 0 & & & & -1 & -1 & -2 & -2 & -1 & -1 & -1 & -1 & -1 \\
\hline 0 & -1 & -1 & 0 & & & & & & -1 & -1 & & & & -2 & -2 & -2 \\
\hline 0 & -1 & -1 & -1 & -1 & -1 & -2 & -1 & -1 & -1 & -1 & & -1 & -1 & -1 & -1 & -1 \\
\hline & -2 & & & & & & & & & & & & & & & \\
\hline & & -2 & & & -2 & -1 & -1 & -1 & -1 & -1 & & -1 & -1 & -1 & -1 & -1 \\
\hline-2 & & & & & & & & & & & & & & & & \\
\hline 1 & -1 & -1 & 0 & 0 & -1 & 0 & 0 & -1 & 0 & -1 & & -1 & -1 & 0 & 0 & 0 \\
\hline & & -1 & & & -1 & & & -1 & & & & & & & & \\
\hline 0 & -1 & & -1 & & -1 & -1 & -2 & & -1 & & & & -1 & 0 & -1 & 0 \\
\hline & & & & -2 & -2 & & & & -2 & & -2 & & & & & \\
\hline & & -1 & -2 & & -1 & & & & & & & & & & & \\
\hline-1 & -1 & & & & 0 & & -1 & -1 & -1 & 0 & -2 & -1 & 0 & 0 & 0 & 0 \\
\hline & & & & & & & & & & & & & & -1 & -1 & -1 \\
\hline & & & & & & & & & & $?$ & & & & 0 & 0 & 0 \\
\hline
\end{tabular}


TABLE 18 - Continued

\begin{tabular}{|c|c|c|c|c|c|c|c|c|c|c|c|c|}
\hline \multicolumn{12}{|c|}{ LATE PLIOCENE } & 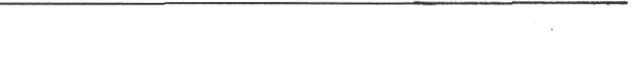 \\
\hline \multicolumn{12}{|c|}{ Sphenolithus abies } & \\
\hline \multicolumn{4}{|c|}{$78.6-87.8$} & \multicolumn{5}{|c|}{$87.8-96.9$} & \multicolumn{3}{|c|}{$96.9-106.1$} & \\
\hline \multicolumn{4}{|c|}{5} & \multicolumn{5}{|c|}{6} & \multicolumn{3}{|c|}{7} & \\
\hline \multicolumn{4}{|c|}{1} & \multicolumn{5}{|c|}{2} & \multicolumn{3}{|c|}{1} & \\
\hline 38 & 81 & 103 & 117 & 50 & 100 & 2 & 50 & 100 & 36 & 101 & 142 & \\
\hline 0 & 0 & 0 & 0 & 1 & 0 & 0 & -1 & 0 & 0 & 0 & -1 & \\
\hline-1 & -1 & -1 & -1 & 1 & 0 & 0 & 0 & 0 & 0 & 0 & -1 & \\
\hline-1 & -1 & -1 & -2 & -1 & & & -1 & & & & & \\
\hline 1 & 1 & 1 & 1 & 1 & 0 & 1 & 0 & 1 & 0 & 0 & 0 & \\
\hline 0 & 0 & 0 & -1 & 0 & -1 & 0 & -1 & -1 & -1 & -1 & & \\
\hline-1 & -1 & -1 & -2 & -1 & & & & 0 & 0 & 0 & & \\
\hline 0 & 0 & 0 & -2 & 0 & -1 & & -1 & -1 & -1 & -1 & & \\
\hline \multirow[t]{3}{*}{0} & 0 & 0 & -2 & -2 & & & & -1 & -1 & -1 & & \\
\hline & -2 & & & & & & & & & & & \\
\hline & & & & & -2 & -2 & & & & -2 & & \\
\hline \multirow[t]{2}{*}{0} & 0 & 0 & & 0 & & 0 & & 0 & 0 & 0 & & \\
\hline & & & & & & & -2 & & & & & \\
\hline 0 & -1 & & & & & & & & & & & \\
\hline \multirow[t]{2}{*}{-2} & -2 & & & & & & & & & & & \\
\hline & & & & & & -1 & & & & & & \\
\hline 0 & 0 & 0 & -1 & 0 & -1 & 0 & -1 & 0 & 0 & 0 & -1 & \\
\hline 0 & 0 & 0 & -1 & 1 & & 1 & -1 & 0 & 0 & 0 & 0 & \\
\hline 0 & & & & & & & & & & & -1 & \\
\hline
\end{tabular}




\begin{tabular}{l|l|}
\hline & Age \\
\hline & Zone \\
\hline & Depth Below Sea Floor in Meters \\
\hline & Core Number \\
\hline & Section Number \\
\hline & Depth in Section in Centimeters \\
\hline & Gephyrocapsa caribbeanica \\
\hline & Pseudoemiliania lacunosa (circular) \\
\hline & Pseudoemiliania lacunosa (elliptical) \\
\hline & Coccolithus pelagicus \\
\hline & Reticulofenestra pseudoumbilica \\
\hline & Cyclococcolithus leptoporus \\
\hline & Umbilicosphaera mirabilis \\
\hline & Helicopontosphaera kamptneri \\
\hline & Helicopontosphaera wallichi \\
\hline & Helicopontosphaera cf. seminulum \\
\hline & Pontosphaera scutellum \\
\hline & Pontosphaera discopora \\
\hline & 'Discolithina" phaseola \\
\hline & Aspidorhabdus stylifer \\
\hline & Rhabdosphaera clavigera \\
\hline & Ceratolithus cristatus \\
\hline & Scapholithus fossilis \\
\hline & Discoaster brouweri rutellus \\
\hline & Discoaster pentaradiatus \\
\hline & Sphenolithus abies \\
\hline
\end{tabular}


TABLE 19

Distribution of Calcareous Nannofossils in Cores 8-10, Site 31

\begin{tabular}{|c|c|c|c|c|c|c|c|c|c|c|c|c|c|c|c|c|c|}
\hline \multicolumn{5}{|c|}{ MIDDLE MIOCENE } & & & & \multicolumn{9}{|c|}{ LATE OLIGOCENE } & Age \\
\hline \multicolumn{5}{|c|}{ Discoaster exilis } & \multicolumn{3}{|c|}{$\begin{array}{llll} & ? & ? & ?\end{array}$} & \multicolumn{9}{|c|}{ Triquetrorhabdulus carinatus } & Zone \\
\hline \multicolumn{5}{|c|}{$154.8-164.0$} & \multicolumn{3}{|c|}{$212.1-221.3$} & \multicolumn{9}{|c|}{$270.1-279.2$} & Depth Below Sea Floor in Meters \\
\hline \multicolumn{5}{|c|}{8} & \multicolumn{3}{|c|}{9} & \multicolumn{9}{|c|}{10} & Core Number \\
\hline \multicolumn{2}{|c|}{1} & \multicolumn{3}{|c|}{2} & 2 & \multicolumn{2}{|c|}{3} & \multicolumn{2}{|c|}{1} & \multicolumn{2}{|c|}{2} & \multicolumn{2}{|c|}{3} & \multicolumn{2}{|c|}{4} & 5 & Section Number \\
\hline 46 & 102 & 1 & 50 & 100 & 1 & 4 & 90 & 4 & 107 & 6 & 91 & 3 & 83 & 3 & 93 & 122 & Depth in Section in Centimeters \\
\hline 0 & 0 & 0 & 0 & 0 & 0 & 0 & 0 & 1 & 1 & 1 & 1 & 1 & 1 & 1 & 1 & 1 & Coccolithus pelagicus \\
\hline-1 & -1 & -1 & -1 & -1 & & & & 0 & 0 & 0 & 0 & 0 & 0 & 0 & 0 & 0 & Coccolithus eopelagicus \\
\hline 1 & 1 & 1 & 1 & 1 & & & & & & & & & & & & & Reticulofenestra pseudoumbilica \\
\hline & & & & & 0 & 0 & 0 & -1 & 0 & 0 & 0 & 0 & 0 & 0 & 0 & 0 & Cyclococcolithus floridanus \\
\hline-1 & & & & & & & & & & & & & & & & & Coronocyclus nitescens \\
\hline 0 & 0 & 0 & 0 & 0 & 0 & 0 & 0 & & & & & & & & & & Helicopontosphaera intermedia \\
\hline-1 & -1 & -1 & -1 & -1 & & & & & & & & & & & & & Discoaster brouweri rutellus \\
\hline-1 & 0 & -1 & -1 & -1 & & & & & & & & & & & & & Discoaster extensus \\
\hline-1 & -1 & -1 & -1 & -1 & & & & & & & & & & & & & Discoaster variabilis \\
\hline-1 & -1 & -1 & -1 & -1 & & & & & & & & & & & & & Discoaster exilis \\
\hline-1 & -1 & -1 & -1 & -1 & & & & & & & & & & & & & Discoaster cf. bollii \\
\hline & & -1 & & & 0 & 0 & 0 & -1 & 0 & 0 & 0 & 0 & 0 & 0 & 0 & 0 & Discoaster deflandrei \\
\hline & & & & & 0 & 0 & 0 & -1 & 0 & 0 & 0 & 0 & 0 & 0 & 0 & 0 & Discoaster nephados \\
\hline & & & & & & & & & & -1 & & & -1 & -1 & -1 & 0 & Discoaster trinidadensis \\
\hline$?$ & & & & & & & -1 & -1 & & & & -1 & & 0 & 0 & 0 & Discoaster lidzi \\
\hline 0 & 0 & 0 & 0 & 0 & 0 & 0 & 0 & 0 & 0 & 0 & 0 & 0 & 0 & 0 & 0 & 0 & Sphenolithus abies \\
\hline & & & & & & & -2 & & & & & & & & & & Sphenolithus moriformis \\
\hline & & & & & & & & -1 & & & & & & & & & Sphenolithus heteromorphus \\
\hline & & & & & & & & 0 & 1 & 1 & 1 & 1 & 1 & 1 & 1 & 1 & Triquetrorhabdulus carinatus \\
\hline
\end{tabular}


Loeblich, A. R., Jr. and Tappan, H., 1969. Annotated index and bibliography of the calcareous nannoplankton III. J. Paleontol. 43, 568

Martini, E. and Bramlette, M. N., 1963. Calcareous nannoplankton from the experimental Mohole drilling. J. Paleontol. 37, 845.
McIntyre, A. and Bé, A. W. H., 1967. Modern Coccolithophoridae of the Atlantic Ocean-I. Placoliths and crytoliths. Deep-Sea Res. 14, 561.

Tan Sin Hok, 1927. Discoasteridae incertae sedis. Sect. Sci. Koninkl. Ned. Akad. Wetenschap. Proc. 30, 411. 